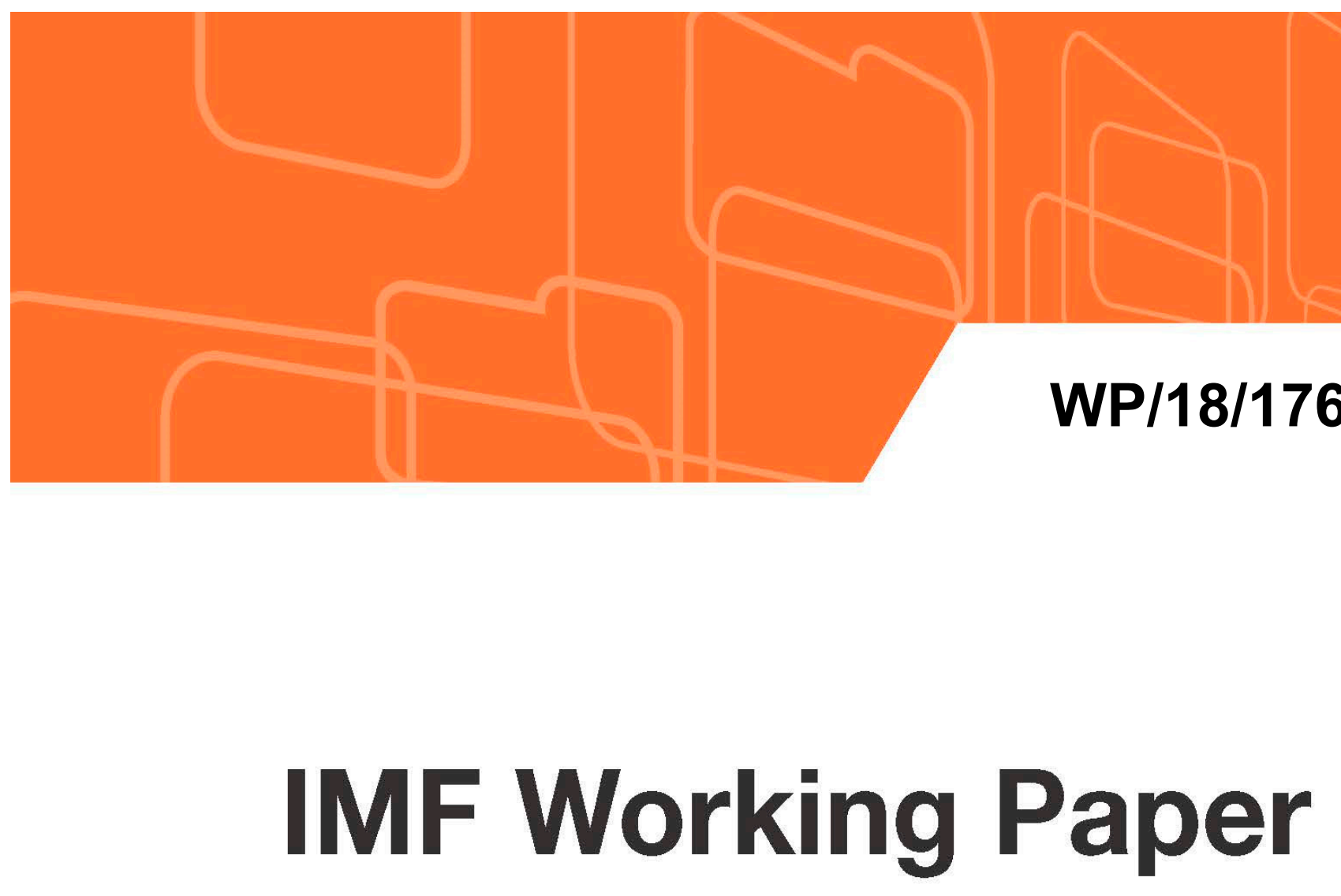

\title{
Legal Protection: Liability and Immunity Arrangements of Central Banks and Financial Supervisors
}

by Ashraf Khan

IMF Working Papers describe research in progress by the author(s) and are published to elicit comments and to encourage debate. The views expressed in IMF Working Papers are those of the author(s) and do not necessarily represent the views of the IMF, its Executive Board, or IMF management. 


\title{
IMF Working Paper
}

Monetary and Capital Markets Department

\section{Legal Protection: Liability and Immunity Arrangements of Central Banks and Financial Supervisors}

\section{Prepared by Ashraf Khan}

Authorized for distribution by Jihad Alwazir

August 2018

\section{IMF Working Papers describe research in progress by the author(s) and are published to elicit comments and to encourage debate. The views expressed in IMF Working Papers are those of the author(s) and do not necessarily represent the views of the IMF, its Executive Board, or IMF management.}

\begin{abstract}
This paper argues that central bank legal protection contributes to safeguarding a central bank and its financial supervisor's independence, especially for conducting monetary and financial stability policy. However, such legal protection also entails enhanced accountability. To this end, the paper provides a selected overview of legal protection for central banks and financial supervisors (if the supervisor is part of the central bank), focusing on liability, immunity, and indemnification arrangements, and based on the IMF's Central Bank Legislation Database. The paper also uses data from the IMF's Article IV and FSAP Database, and the IMF MCM's Technical Assistance Database. It lists selected country cases for illustrative purposes. It introduces the concepts of "appropriate legal protection" and "function-specific legal protection" as topics for further research.

JEL Classification Numbers: E50, E52, E58, F33, G18, G28, K00, K40

Keywords: central banking, financial supervision, financial regulation, law, liability, immunity, technical assistance

Author's Email Address: AKhan4@imf.org

The author is grateful for comments from Thérèse Couture, Antonio Pancorbo, Ralf Tutsch, and Carla Vaszuez, as well as input and comments from the central banks of Colombia, Cyprus, India, Israel, Philippines, and Thailand. Claudia Jadrijevic and Mark Engher provided invaluable assistance with the IMF's databases. Emily Collinson provided helpful Excel support. Jay Chang, Lilit Makarayan, and Danica Owczar tirelessly assisted with formatting and editing. A very special thanks to Marcela Matamoros for her comprehensive legal advice. All remaining errors are my own.
\end{abstract}


Glossary .5

I. Introduction: Changing Roles of Central Banks.............................................................

II. Central Bank Governance: Legal Protection as a balance between Independence and Accountability. 8

III. Frameworks for Central Bank Legal Protection ......................................................11

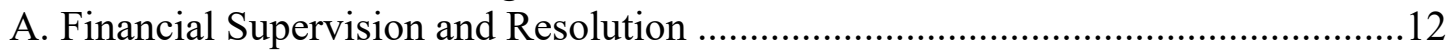

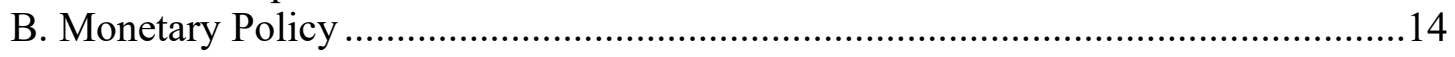

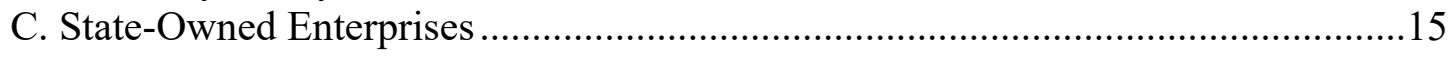

IV. Central Bank Legal Protection Arrangements ............................................................ 15

A. Protection Against Whom ....................................................................... 17

B. Protection Against What: Immunity/Exclusion of Liability .............................. 17

C. Protection in What Area ..............................................................................21

D. Who is Protected Subjects........................................................................... 22

E. Protected Against What: Standards ..................................................................23

F. Protected in What Manner: Indemnification .................................................24

G. Limitations to Protection: Fines and Sanctions.................................................26

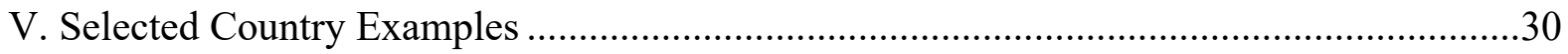

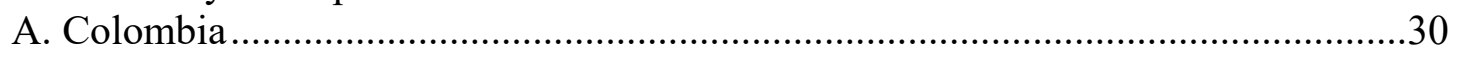

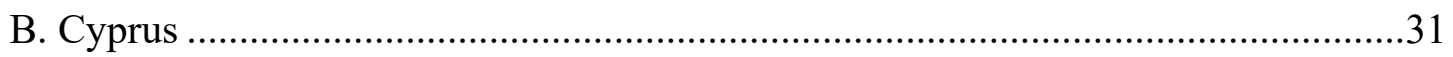

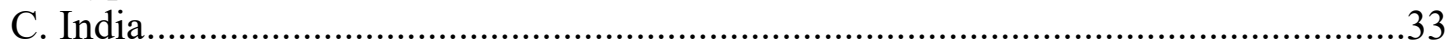

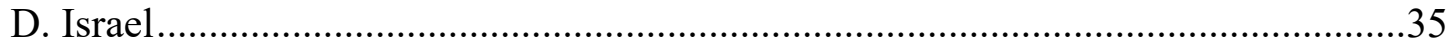

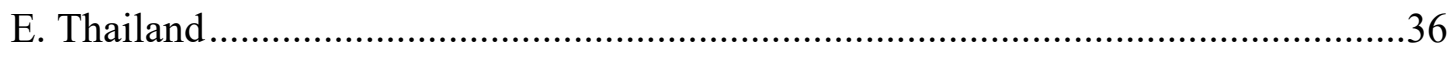

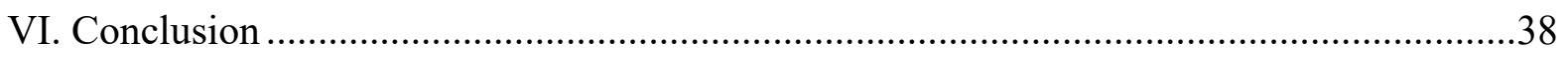

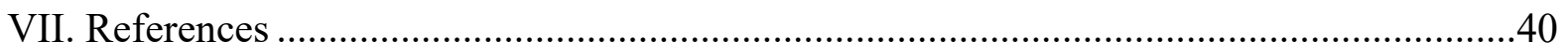


Figures

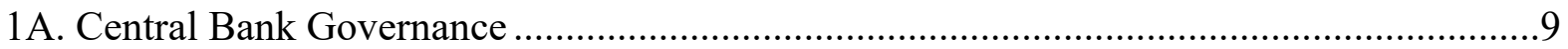

1B. Central Bank Legal Protection .................................................................................... 11

2. Liability Regimes for Central Banks and Financial Supervisors ......................................12

3. Elements of a Conceptual Framework for Legal Protection...............................................12

4. Combined Central Banks and Financial Supervisors................................................... 14

5. References to Liability in Central Bank Laws ............................................................... 18

6. MCM TA Reports - Geographical Breakdown................................................................ 18

7. MCM TA Reports - Time Periods .................................................................................. 19

8. MCM TA Reports - Scope of Liability............................................................................ 19

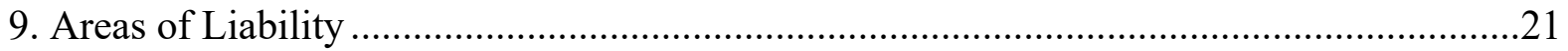

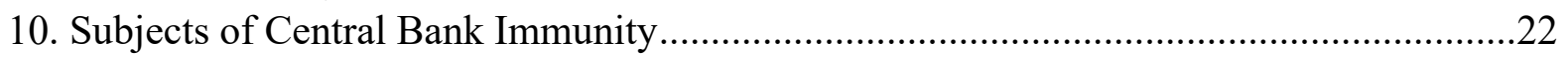

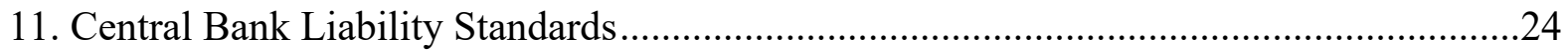

12. Central Bank Law Indemnification Arrangements ........................................................24

13. Central Bank Laws with Sanctions .............................................................................27

14. Maximum Average Fines in Central Bank Laws.........................................................28

15. Maximum Average Imprisonment Terms in Central Bank Laws..................................29

Annex

I. Overview of Selected News Articles on Central Bank Court Cases ..................................42 


\section{GLOSSARY}

$\begin{array}{ll}\text { AML/CFT } & \text { Anti-Money Laundering/Combatting the Financing of Terrorism } \\ \text { BCBS } & \text { Basel Committee on Banking Supervision } \\ \text { BdlR } & \text { Banco de la República } \\ \text { BIS } & \text { Bank for International Settlements } \\ \text { BOI } & \text { Bank of Israel } \\ \text { BOT } & \text { Bank of Thailand } \\ \text { CBC } & \text { Central Bank of Cyprus } \\ \text { CBI } & \text { Central Bank Independence } \\ \text { CBLD } & \text { Central Bank Legislation Database } \\ \text { ECB } & \text { European Central Bank } \\ \text { FSAP } & \text { Financial Sector Assessment Program } \\ \text { FSB } & \text { Financial Stability Board } \\ \text { GFC } & \text { Global Financial Crisis } \\ \text { IMF } & \text { International Monetary Fund } \\ \text { MCM } & \text { Monetary and Capital Markets Department, IMF } \\ \text { MPC } & \text { Monetary Policy Committee } \\ \text { OECD } & \text { Organisation for Economic Co-operation and Development } \\ \text { RBI } & \text { Reserve Bank of India } \\ \text { SOE } & \text { State-Owned Enterprise } \\ \text { SWF } & \text { Sovereign Wealth Fund } \\ \text { TA } & \text { Technical Assistance }\end{array}$




\section{Introduction: Changing Roles of CEnTRAL BANKS}

Over the past decade, central banking has changed significantly. In the decades before the Global Financial Crisis (GFC), central banks predominantly focused on their price stability mandate, had reasonably high levels of independence ${ }^{1}$, and, often, microprudential supervision was dealt with by a separate agency or authority. The GFC impelled central banks to focus on matters affecting financial stability, including macroprudential and microprudential functions. ${ }^{2}$ However, these efforts led some politicians to claim that central banks were acting beyond their legal mandates. ${ }^{3}$

Central bank roles and responsibilities are varied and wide. The financial stability component functions as a "catchall" for issues that in one way or another could affect society at large. Recent Financial Stability Board (FSB) agendas indicate that central bankers and financial supervisors are actively discussing topical issues, such as climate change, Fintech and cyber risks, gender diversity, compliance, sustainability, and risk culture. ${ }^{4}$ Numerous central banks have had to deal with financially troubled banks, and on the monetary policy side, significantly expand their balance sheets by conducting unconventional activities, including quantitative easing. The attempted integration of a host of functions into one entity means that central bank mandates can range from price and financial stability to consumer protection, financial integrity, and economic development in general.

These broad central bank mandates, and the institutional independence necessary for the central bank, require enhanced accountability. Accountability mechanisms vary widely across central banks. Often, central bankers will need to demonstrate to government that their powers have been used appropriately, or, in other words, demonstrate accountability (Section II). Different forms of transparency are employed to provide for a central bank's accountability, such as disclosure of information relating to the central bank's mandate, its internal organization, its policies, operations, outcome, and relations with government. These could take the shape of published minutes, reports to Parliament, parliamentary hearings

\footnotetext{
${ }^{1}$ This paper will refer to "independence" instead of "autonomy," as most economic literature does so (and uses the acronym "CBI" for central bank independence). See Khan (2017) for an overview of relevant CBI literature. Section II discusses the various forms of independence.

${ }^{2}$ See also Khan (2017), BIS (2011), and BIS (2009).

${ }^{3}$ See, for instance, bipartisan pleas in the US for stronger oversight on policies of the Federal Reserve (and the subsequent Financial CHOICE Act); the UK's Jeremy Corbyn's criticism on the ECB QE program, stressing the need for "people's QE," and the criticism by UK Parliamentarians on the lack of oversight and audit of the Bank of England, and out-of-mandate involvement on topics such as climate change and ethics.

${ }^{4}$ See, for instance, October 6, 2017, press statement on the FSB 2018 work plan, and references to cybersecurity, addressing misconduct risk and market-based finance. Also, see the FSB's webpage dedicated to "Additional Policy Areas," including references to developing climate-related financial disclosures and the monitoring of Fintech.
} 
involving the Governor, open letters indicating deviations from preset monetary policies, and one-on-one discussions between the Governor and the Minister of Finance-all tools to allow the central bank to explain its actions, and be held accountable.

The paper is organized as follows: the various sections examine central bank governance (independence, accountability, and legal protection (Section II), frameworks for central bank legal protection (Section III, based on the IMF's Central Bank Legislation Database, and other relevant IMF findings), central bank legal protection arrangements (Section IV), and selected country examples (Section V). Section VI provides a conclusion.

Central bank laws ${ }^{5}$ are used as the main source for the paper's findings. A legal framework that exclusively protects central banks, their decision-makers, staff, and others will need to be embedded in the law governing the central bank. This is similar to, for instance, central bank-specific secrecy and confidentiality arrangements, given the specific mandate of the central bank. Additionally, legal systems and traditions differ significantly across countries, and any comparison beyond the central bank laws would need to include detailed legal country-by-country analysis. Section IV, therefore, will examine only the legal protection arrangements of central banks and financial supervisors, as based on central bank legislation.

Box 1 provides an overview of the relevant terminology used throughout the paper.

Box 1. Terminology

The following definitions are used in this paper:

1) Legal protection: the safety provided to the central bank and financial supervisor from liability.

2) Appropriate protection: the specific form of legal protection that balances central bank and supervisory accountability (in the form of liability) with independence (in the form of immunity).

3) Liability: the explicit acceptance of responsibility for actions and omissions by civil, criminal, and administrative law.

4) Immunity: protection of public institutions, their decision-makers, staff and other officials from liability for their actions and omissions.

5) Indemnification: legal and financial support in case of liability issues. This could refer to central banks and governments compensating Board and staff members for legal representation and other legal defenserelated costs, or providing direct legal assistance.

6) Legal arrangements: any form of legal documentation (constitution, law, jurisprudence) that provides guidance for the protection of central banks and financial supervisors, their decision-makers, staff, and other officials, and deals with liability, immunity, and indemnification-related issues.

\footnotetext{
${ }^{5}$ That is to say, central bank (organic) laws, and excerpts of Constitutions (where applicable) — not the entire legal framework governing the central bank.
} 


\section{Central Bank Governance: Legal Protection as a balance between INDEPENDENCE AND ACCOUNTABILITY}

Central bank governance is the starting point for determining the appropriate level of legal protection. Central bank governance relates to the intricate connection between what a central bank is supposed to do (its legal mandate, embedded within the overall legal framework), the central bank's freedom to make policy choices to achieve those goals (its independence), the way it provides explanations of policy choices (its accountability), and the internal means to support its decision-making (its internal organization). The more independent a central bank, the more answerable it needs to be to State and society.

Central bank independence can be divided into four main categories:

1. Policy, or institutional independence: the central bank has freedom of policy decisionmaking ${ }^{6}$, with its mandate clearly defined in legislation.

2. Operational independence: the central bank is prohibited from seeking or taking instructions from any private or public body. Third parties are prohibited from approving, suspending, annulling, or deferring central bank decisions.

Representatives of third parties should not have the right to vote when they participate in central banks' decision-making bodies.

3. Personal independence: the central bank provides adequate security of tenure for the members of its decision-making bodies. The minimum term of office should be longer than the electoral cycle. More than one authority should be involved in appointment or dismissal (a so-called "double veto" procedure). Clear eligibility requirements are needed, prohibiting government officials and politicians from appointment to a central bank's decision-making bodies (at least as full voting members). Members of those decision-making bodies should be protected from arbitrary dismissal.

4. Financial independence: The central bank can continuously avail itself of sufficient financial resources to fulfill its mandate ("policy solvency"). The central bank is always sufficiently capitalized. Government is required to automatically recapitalize the central bank in case its capital falls below its authorized capital level. There are clear rules for the determination of a central bank's budget, and the distribution of net profits and losses. The central bank accounts are drawn up in line with internationally

\footnotetext{
${ }^{6}$ A further distinction can be made based on the degree of policy independence, into (1) goal independence; (2) target independence; and (3) instrument independence. See Lybek (2004).
} 
recognized standards. There is a prohibition of, or clear limitation on, providing loans to government, other public entities, and on other forms of fiscal financing.

The goal of central bank governance, including its independence arrangements, is to support the mission of the central bank. The central bank's mandate, its independence, accountability and transparency arrangements, and organization all contribute to establishing credibility and trust in the central bank, the market, and the financial sector. See figure 1A for a schematic overview; for a more detailed discussion, see Khan (2016).

Figure 1A. Central Bank Governance

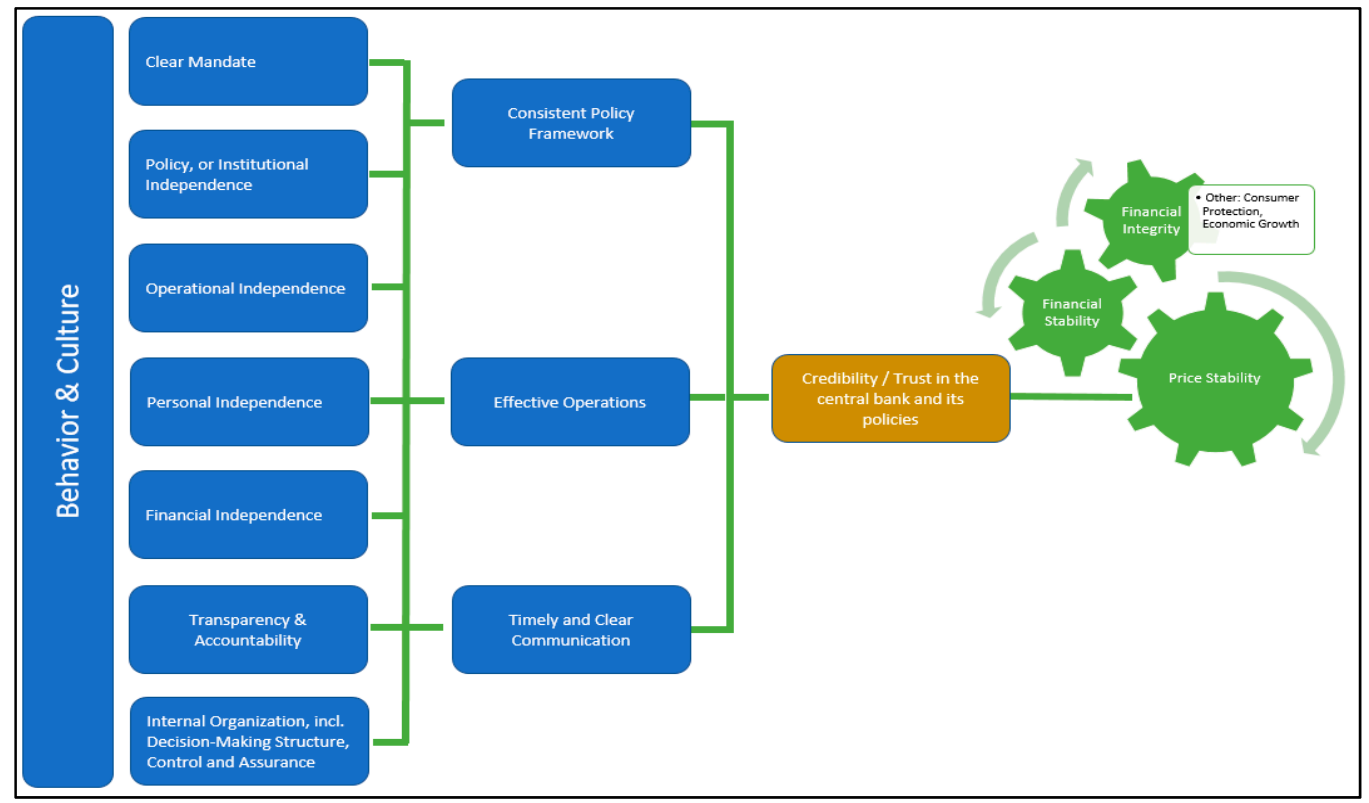

Source: Author (based on Khan 2016).

Central bank independence is crucial to the effective formulation of monetary policy. Wachtel (2017) finds the rise in the importance of central bank independence is based on four factors: "a) interest in central bank legislation and constitutions; b) reaction to high inflation; c) macro theoretical developments and d) the empirical evidence." Central bank independence "is essential to constrain the ability of a central government to use the printing presses to finance expenditure." From a monetary policy perspective, it is important that political influence, which often is focused on a shorter time-period, is avoided in the decision-making process.

Similarly, financial supervision also requires independence. As discussed further in Section III (A), there is widespread agreement on the operational independence of a financial supervisor, based on the Basel Core Principles on Banking Supervision (BCBS). However, there might be differences - depending on the specific function of a country's central bankin the level of independence that is required for the central bank. Supervision-and 
resolution - functions are often related to government's providing some form of financing, whether in the form of financing the supervisory authorities, or bearing the costs of bailing out commercial financial institutions, which would likely require a more stringent method of accountability for the central bank's/supervisor's/resolution authority's actions in those areas.

Independence could be safeguarded by legal immunity. Being insulated from liability could provide an incentive for central banks to make policy decisions without undue influence, or the threat of potentially significant legal consequences, such as fines, or even imprisonment.

Accountability is the counterbalance to central bank independence, and could be safeguarded by legal liability. Central banks and financial supervisors need to be held accountable for the freedom they have been given to make important policy decisions, and for the consequences of those decisions, as Section I notes. Allowing a central bank, its decision-makers, its staff, and possibly others to be taken to court for actions taken or not taken, and for possible resulting damages, provides a legal form of accountability.

However, liability raises the issue of whether the State and its entities can be held fully or partially liable. ${ }^{7}$ The mandate of the State is unique, and its public duties are often in areas prone to significant risk, such as health care, infrastructure, defense, and education, as well as central banking and financial supervision. Allowing State entities, and in particular, the central bank and financial supervisor, to be extensively liable could pose the risk of paralyzing the institution, and incentivize its decision-makers to avoid risks in their decisions.

Therefore, legal protection needs to be appropriate, and possibly function-specific, providing a balance between independence and accountability. This protection can take the form of excluding liability altogether, providing immunity or limiting the liability of the central bank, including its decision-makers, staff, and others, while also providing indemnification for those cases where legal actions are made against the central bank. This would allow the central bank to operate without the fear of having to deal with numerous court cases, or having to allocate significant resources to legal issues. Yet, at the same time, limitations to legal protection, such as liability in specific cases, could give shape to the central bank's duty to be held accountable for its actions. As such, "appropriate protection" depends on the specific country, and on relevant contextual issues. This includes the overall legal framework and legal tradition, the functioning of the judicial system, as well as the position of the central bank within the country, and within the government. Legal protection could be

\footnotetext{
${ }^{7}$ It should be noted that among most jurisdictions, the liability standards differ significantly depending on the state function.
} 
differentiated depending on the function ${ }^{8}$ and/or on the official-though in all cases it would need to strike a balance between strengthening independence and ensuring accountability (Figure 1B).

Figure 1B. Central Bank Legal Protection

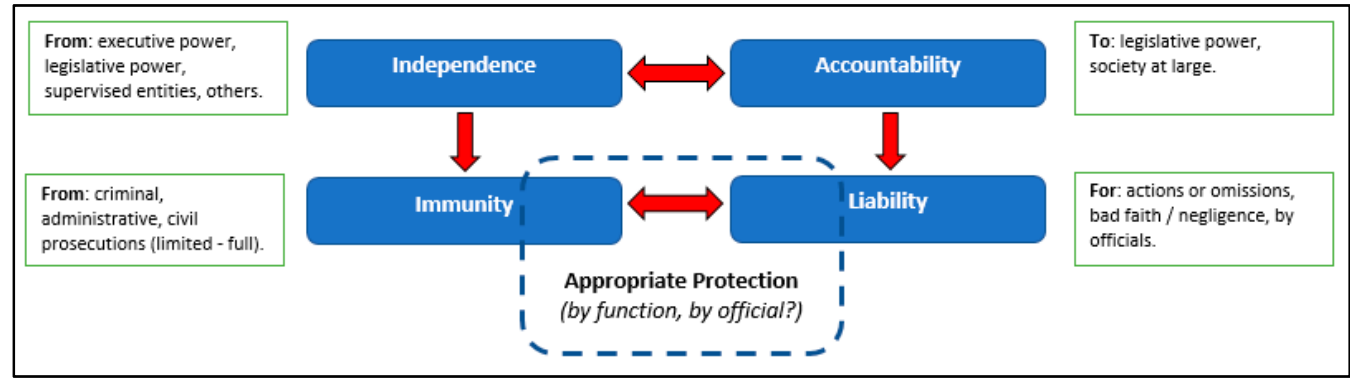

Sources: Author and Marcela Matamoros.

Several central banks listed in Section IV, and in Annex I, have arrangements to provide accountability over their legal protection. Examples include reporting to the Minister of Finance and reporting to Parliament. The selected central bank cases in Section V provide clear examples of how legal protection is embedded in domestic legislation, how these central banks provide transparency over the actions and omissions of their decision-makers and staff, and how they are being held accountable. Examples include court procedures involving either the central bank or individual decision-makers, or even individual central bank staff and external agents.

The research findings of Section IV and the country examples of Section V indicate that central bank legal protection is a powerful tool for supporting central bank independence. Before examining these findings, the next section first outlines existing frameworks for central bank legal protection.

\section{Frameworks for Central Bank Legal Protection}

A distinction between different forms of central bank liability is necessary. A liability framework addresses several key issues, such as who would be liable, under what circumstances, and what possible exclusions might exist. Dijkstra (2012) divides liability regimes into fault liability and no-fault liability: the former, implying an attributable fault to the central bank, and the latter, assuming liability consequences, even in the absence of such a fault. Fault liability itself can be divided into negligent conduct (that is, the fault arises out of negligence of the central bank), and intentional conduct (that is, the fault is the

\footnotetext{
${ }^{8}$ See, for instance, Section III regarding the function-specific legal protection requirements for supervision (based on the BCBS Core Principles for Effective Supervision), and resolution (based on the FSB's Key Attributes of Effective Resolution Regimes).
} 
consequence of foreseen and intended actions taken by the central bank), or, in other words, "bad faith." Finally, negligent conduct can be divided into simple negligence and gross negligence (Figure 2).

Figure 2. Liability Regimes for Central Banks and Financial Supervisors

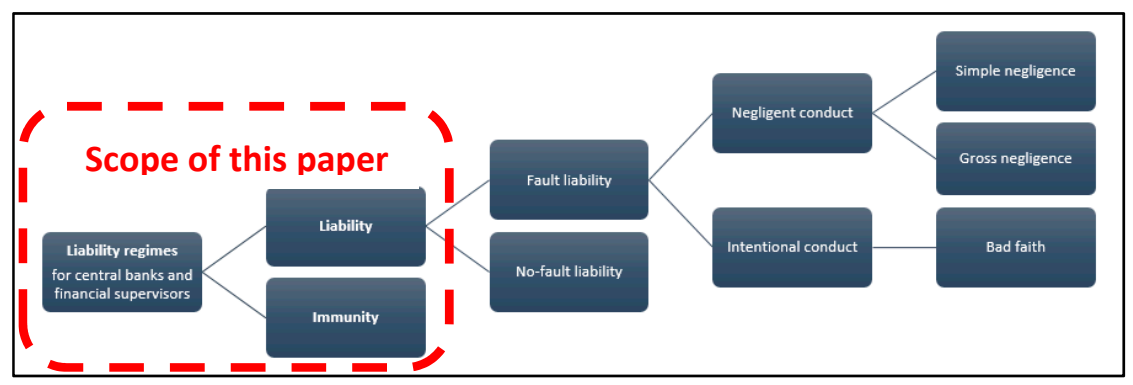

Source: Dijkstra (2012).

Additionally, there are different international frameworks relevant for liability arrangements. The two main sets of principles relate to financial supervision and resolution, and to monetary policy. One additional body of principles relates to State-Owned Enterprises and Sovereign Wealth Funds. These are examined respectively in subsections A, B, and C.

\section{A. Financial Supervision and Resolution}

Legal protection is a key element of supervisory and resolution frameworks. Regarding the resolution function of central banks, Arda (2013) stresses that though many jurisdictions have some form of legal protection framework for entities conducting prudential supervision and bank resolution, there "is room for further clarifications, which is necessary in particular in light of increased resolution powers." He stresses that resolution "will be under heightened public scrutiny because resolution activities are more intrusive than regular supervisory decisions, and may involve large sums of public money." He proposes a conceptual framework for legal protection, which covers a number of key questions (Figure 3), which can also be extended beyond resolution.

Figure 3. Elements of a Conceptual Framework for Legal Protection

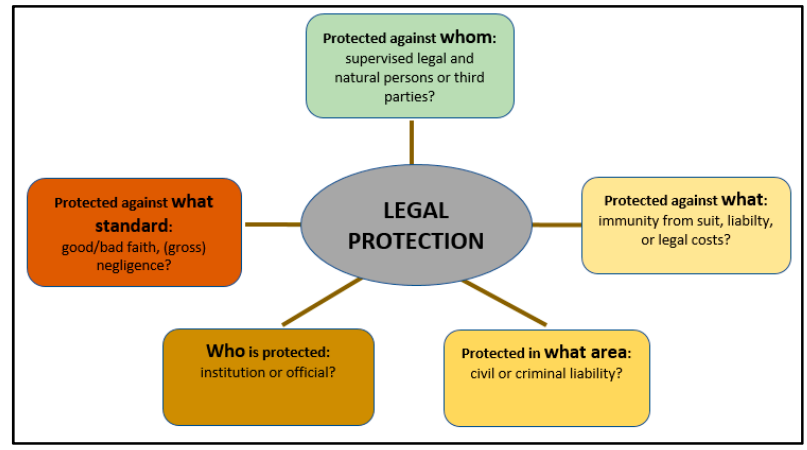

Source: Arda (2013) 
Legal protection for financial supervisors is highlighted in the Basel Core Principles. In cases where the central bank is also the financial supervisor, liability arrangements are covered in the BCBS Core Principles for Effective Supervision, and are linked to the requirement for the operational independence of the supervisor:

Principle 2. Independence, accountability, resourcing, and legal protection for supervisors: The supervisor possesses operational independence, transparent processes, sound governance, and budgetary processes that do not undermine autonomy and adequate resources, and is accountable for the discharge of its duties and use of its resources. The legal framework for banking supervision includes legal protection for the supervisor (italics added, AK).

And Principle 2. Essential Criteria (no. 9):

Laws provide protection to the supervisor and staff against lawsuits for actions taken and/or omissions made while discharging their duties in good faith. The supervisor and staff are adequately protected against the costs of defending their actions and/or omissions made while discharging their duties in good faith.

Similarly, in the IMF's paper on good supervision, legal protection is listed as an element promoting the willingness to take action and fulfill the supervisory role: ${ }^{9}$

Operational independence. Supervisory agencies should be able to resist inappropriate political interference or inappropriate influence from the financial sector itself; this needs to be reflected in the processes for appointment and dismissal of senior staff, stable sources of agency funding, and adequate legal protection for staff (italics added, AK).

A separate law on financial supervision might also hold more specific legal protection arrangements for financial supervision actions undertaken by the central bank. See, for instance, the Slovak Republic, where the Act on the Národná Banka Slovenska does not contain any reference to the liability of the central bank. However, Article 42 sub 1, the Act on Supervision of the Financial Markets (no. 747/2004), indicates that "liability for damage caused by the National Bank of Slovakia during the exercise of public authority within the scope of supervision of the financial market shall be stipulated by a separate law." As mentioned, this paper will focus on central bank laws only, and will only indicate a reference to other relevant domestic legislation if the central bank law contains such a reference.

Currently, the majority of central banks are either partially or fully responsible for the financial supervision of banks. As Figure 4 demonstrates, out of the 143 central banks and

\footnotetext{
${ }^{9}$ IMF (2010), “The Making of Good Supervision: Learning to Say 'No,” SPN/10/08.
} 
monetary unions currently listed in the CBLD, 31 central banks (22 percent) do not have any financial supervision functions, whereas 112 (78 percent) do.

\section{Figure 4. Combined Central Banks and Financial Supervisors}

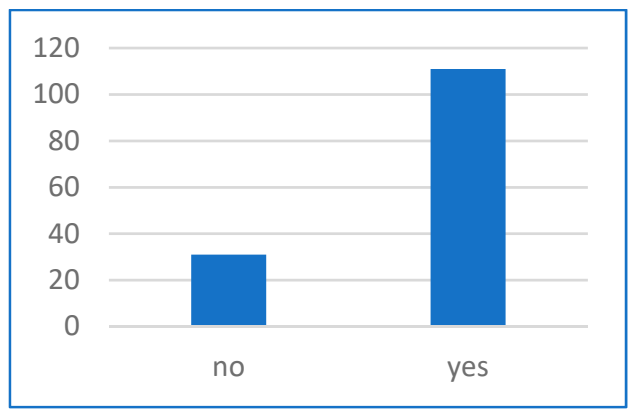

Sources: CBLD (category 9), BIS Overview of Regulatory and Supervisory Agencies, and central bank websites.

For a resolution authority and its staff, the Key Attributes stress legal protection. The Financial Stability Board's (FSB) Key Attributes of Effective Resolution Regimes for Financial Institutions indicates in principle 2.6 (and 4.4, sub [ii]) that the "resolution authority and its staff should be protected against liability for actions taken and omissions made while discharging their duties in the exercise of resolution powers in good faith, including actions in support of foreign resolution proceedings" (italics added, AK).

\section{B. Monetary Policy}

For central banks' monetary policy function, legal liability arrangements are considered necessary as well. The Bank for International Settlements BIS, in its authoritative report on Issues in Central Bank Governance (2009) refers to "repercussions when central bank actions or outcomes are considered unsatisfactory, especially when performance criteria are not met. In particular: about 20 percent of central banks are subject to formal procedures when [inflation, AK] targets are missed. Typically, this involves additional reporting requirements to explain the reasons for missing the target, as well as the measures and time frame needed to meet the target. An example is the open letter that the Governor of the Bank of England is required to write to the Chancellor of the Exchequer if the inflation target is missed by more than 100 basis points." Building on this, as we will see later, some central bank laws contain specific liability arrangements for monetary policy decision-making.

Combining supervision and regulation in the central bank can increase liability risks. The BIS notes that central banks that also have regulatory and supervisory responsibilities must recognize and subsequently manage reputational risks that can arise out of these functions. It also observes that the global financial crisis (GFC) demonstrated that even "when the central bank is not responsible for supervision, it is often perceived as being responsible for financial stability. As a result, its reputation may have become tarnished by 
events for which it was not responsible." The cases listed in Annex 1 serve as an example of such legal risk faced by central banks.

\section{State-Owned Enterprises}

Finally, the Organisation for Economic Co-operation and Development (OECD) stresses the need for State-Owned Enterprises to have clear liability arrangements. Though central banks and financial supervisors are often not seen or treated as State-Owned Enterprises (SOEs) ${ }^{10}$, there are situations where central banks are directly involved with SOEs. Examples include countries where Sovereign Wealth Funds (SWFs) are managed by the central bank (for instance, Chile, Norway ${ }^{11}$, Timor-Leste, and Trinidad and Tobago), or where the central bank is involved (for example, via management) in Public Sector Banks, such as in India. For SWFs, the 2008 Santiago Principles ${ }^{12}$ stress the need for clear accountability arrangements. For SOEs in general, the OECD (2015) highlights that SOE boards "should be fully accountable to the owners, act in the best interest of the enterprise and treat all shareholders equitably," with "collective and individual liability of board members... clearly stated," and without "any difference between the liabilities of different board members, whether they are nominated by the state or any other shareholders or stakeholders."

In conclusion, supervisors and resolution authorities are governed by function-specific legal protection principles, though there are no clear and generally accepted guidelines - in particular for central banks. The BCBS Core Principles and the FSB Key Attributes are clear on the need to provide legal protection for financial supervisors and resolution authorities. The BIS report on central bank governance indicates some preference for limiting the liability of a central bank for its monetary policy, but there is no unified set of principles and guidelines relating to central bank liability that covers the central bank as a whole. We will now examine more closely legal protection arrangements surrounding various central banks to see if and how central bank laws can provide more detailed liability, immunity, and indemnification.

\section{Central Bank Legal Protection Arrangements}

The IMF's Central Bank Legislation Database (CBLD) provides insights into legal frameworks of central banks. The CBLD contains central bank laws and excerpts from the constitutions of 143 IMF member countries and monetary unions, grouped in more than 100

\footnotetext{
${ }^{10}$ Even though some central banks have shares, which are fully (e.g., the Netherlands) or partly (e.g., Belgium, Italy) owned by the State.

${ }^{11}$ The Norwegian Government Pension Fund's global investment fund is managed by Norges Bank Investment Management, part of the Norwegian Central Bank, on behalf of the Ministry of Finance.

${ }^{12}$ International Working Group on Sovereign Wealth Funds, Sovereign Wealth Funds Generally Accepted Principles and Practices, October 2008.
} 
categories. ${ }^{13}$ The database is, at this point, only accessible to staff from international financial institutions, central banks, and monetary unions. ${ }^{14}$

There are several CBLD categories that can provide information on central bank liability. For this paper, the categories 2.06 (Legislation with Direct Implications on the Status of the Central Bank), 2.09 (Prohibited Activities of the Central Bank), and 12.04 (Immunity of the Central Bank from Taxation) were selected. ${ }^{15} \mathrm{~A}$ full text search on all central bank legislation included in the CBLD - central bank laws and excerpts of constitutions - was also applied to the following terms: "immunity," "immunities," "suit," "indemnity," "indemnify," and "liable." Reference is made again to Box 1 (Section I) with regard to relevant legal protection.

The immunity of the central bank from taxation is left out of scope of the CBLD search. Immunity from taxation does not relate to general immunity of the central bank, its management, and its staff for specific actions, as it refers only to frameworks where the central bank does not pay taxes on the financial transactions it conducts, and thus has little relevance for matters of legal recourse. Nevertheless, this relevant CBLD category was still selected for study, in order to check that all articles of central bank legislation in the CBLD might not also refer to general liability or immunity arrangements.

Here the main findings are summarized, as based on Arda's legal protection framework, previously cited. The sources used are the CBLD, as well as the IMF's Article IV (AIV), Financial Sector Assessment Program (FSAP), and Technical Assistance (TA) databases, in the following subsections:

A - Protected against whom

B - Protected against what: immunity/exclusion of liability

$\mathrm{C}-$ Protected in what area

$\mathrm{D}-$ Who is protected

E - Protected against what standard

\footnotetext{
${ }^{13}$ See also A. Khan (2017), Central Bank Legal Frameworks in the Aftermath of the Global Financial Crisis, IMF Working Paper 17/101.

${ }^{14}$ The Supporting Document to the IMF's Code of Good Practices on Transparency in Monetary and Financial Policies, Part 3-Good Transparency Practices for Financial Policies by Financial Agencies (see Box 3-3 Statutory Protection for Officials and Staff of Financial Agencies) provides helpful details on liability arrangements in certain countries. However, given that this information dates back to 2000, the CBLD provides a more accurate overview of legal practices.

${ }^{15}$ Additional CBLD categories that contain references to legal protection are: 2.01, 2.11, 3.02, 3.08, 3.09, 3.10, $3.13,3.19,3.20,3.22,9.02$ (specifically for legal protection of financial supervisors), and 12.06. See Khan (2017).
} 
Two subsections, in addition to the above framework, deal with more granular information:

$\mathrm{F}$ - Protected in what manner: indemnification

$\mathrm{G}$ - Limitations of protection: fines and sanctions

\section{A. Protection Against Whom}

Most central bank laws do not specify against whom they provide protection. Out of the 76 central bank laws ${ }^{16}$ with a reference to central bank liability, the great majority (72) do not contain any references to specific groups, institutions, or individuals that can hold the central bank and its staff liable. There are four exceptions: the laws of the central banks of Turkey and Macedonia contain a reference to "third parties"; the law of the central bank of Chile refers to "interested party"; and the law of the State Bank of Pakistan refers specifically to "any person or participant in the payment and settlement systems."

\section{B. Protection Against What: Immunity/Exclusion of Liability}

Most central bank laws contain an explicit reference to some form of limited central bank liability (Figure 5). A slight majority of 53 percent of central bank laws (76 countries and monetary unions out of 143 countries and monetary unions listed in the CBLD) contain at least one explicit reference to liability arrangements. This could include excluding or including liability for one or more categories of people, or for making specific immunity arrangements. Some countries assume immunity where a Board member voted against a decision (the Dominican Republic, and Trinidad and Tobago), or where explicit consent of a superior was involved (Switzerland). Legal liability could fall under criminal or civil law, or a combination (Subsection C). It should be noted that the existence of legal provisions that refer to liability in a central bank law can have only two purposes: (1) clarifying that the liability regime will be subject to the general national system of liability rules for public officials; and (2) limiting the liability for the general system and offer some kind of protection.

\footnotetext{
${ }^{16}$ In all 76 cases, reference to liability of the central bank is based on the central bank law. Only in the case of Uruguay does the Constitution (article 24) also hold a reference to the civil liability of "autonomous entities, decentralized agencies, and, in general, all government bodies." The central bank law provides a direct reference to the Constitution, and also contains additional liability arrangements affecting the central bank (article 19).
} 


\section{Figure 5. References to Liability in Central Bank Laws}

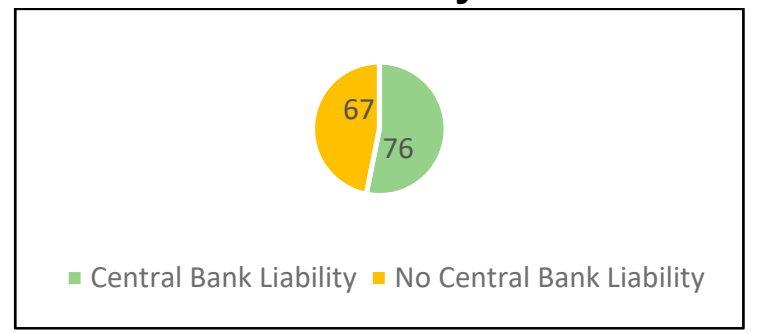

Source: IMF CBLD.

Most central bank laws with liability arrangements exclude liability in one way or another. From the countries that have central bank laws with references to central bank liability, 43 (out of 76) have explicit arrangements for partial exclusion of liability, versus 33 (out of 76) that have no such immunity arrangements, or where the law does not specify if there are immunity arrangements in one form or another.

Similarly, a significant number of IMF technical assistance reports flag issues relating to liability and immunity. A query of the IMF's Monetary and Capital Markets (MCM) internal database ${ }^{17}$ of confidential technical assistance (TA) reports finds 230 links (10 percent) to central bank and/or supervisory liability issues; out of these, 144 (6 percent) relate to unique TA missions. ${ }^{18}$ Most of these missions took place in countries in the European and Asia Pacific regions (Figure 6) and in the pre-GFC period of 2000-08 (Figure 7) ${ }^{19}$. Additionally, the scope of liability in the large majority of cases relates to financial supervision, followed by other central bank issues, and financial crisis management and resolution. Some cases deal with liability issues in the context of anti-money laundering (AML), and securities. An exceptional case relates to liability arrangements for a Sovereign Wealth Fund (SWF). See Figure 8 (note that a single TA report could include multiple scopes).

Figure 6. MCM TA Reports: Geographical Breakdown*

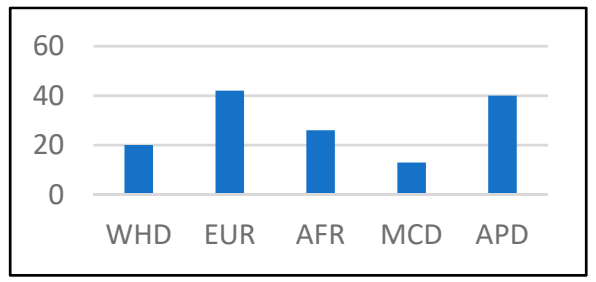

WHD: Western Hemisphere

EUR: Europe

AFR: Africa

MCD: Middle East and Central Asia

APD: Asia Pacific

Source: IMF MCM TA database.

\footnotetext{
${ }^{17}$ The MCM TA database currently consists of 2,259 MCM TA reports from around 1980-2017. Though the database is not complete at this point, it does hold the great majority of MCM TA reports of that period conducted by MCM staff (this excludes reports from Regional Training Centers, and MCM TA missions conducted by short- and long-term experts).

18 "Unique" implies that all liability references for a single mission are counted as 1.

${ }^{19}$ The single case from the $1980-90$ period is not clearly visible in the figure.
} 


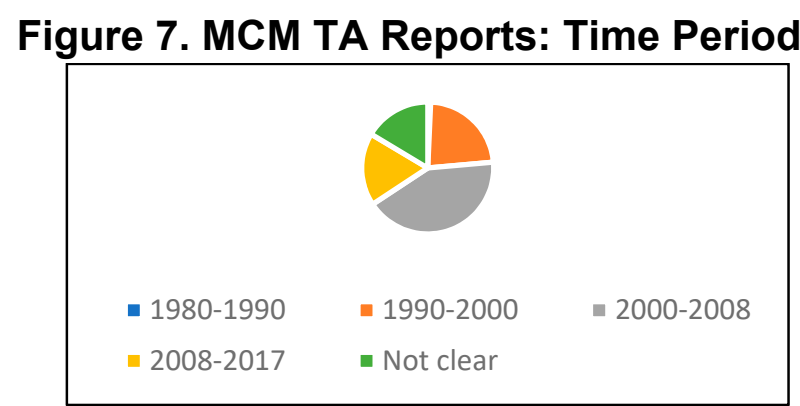

Source: IMF MCM TA database.

Figure 8. MCM TA Reports: Scope of Liability*

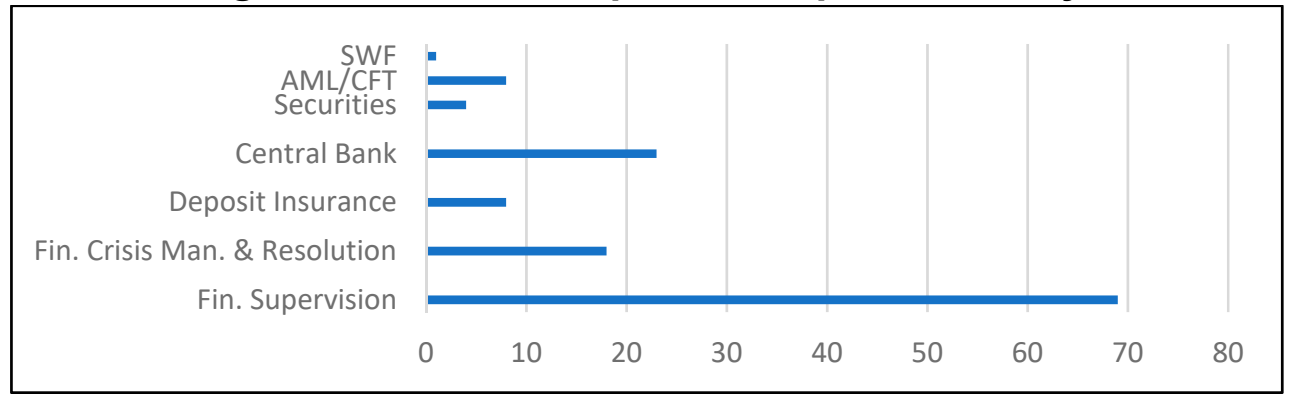

Source: IMF MCM TA database.

* Reflects references to legal protection in central bank laws.

Occasionally, issues arise between the supervisor and the central bank. In the case of one country listed in the MCM TA database, IMF staff found that the independence of the newly founded supervisory agency largely hinged on its isolation from undue interference, not only from government and politicians, but also from the central bank. The assumption was that the central bank would make decisions from a financial stability perspective, which might conflict with microprudential decisions made by the supervisor. Hence, the IMF recommended enhancing the level of immunity granted to the financial supervisor. Of course, such recommendations are dependent on the specific circumstances of a given country.

The IMF's e-Lib database provides surveillance cases relating to liability and immunity. A query ${ }^{20}$ of the e-Lib database ${ }^{21}$ provides numerous results, of which the following six are particularly interesting, as they offer explicit insights into IMF findings and recommendations related to legal protection. In the case of country 1 (2016), the report notes that the "government announced the intention to grant the central bank operational autonomy through a constitutional amendment that provides immunity to directors from lower-court

\footnotetext{
${ }^{20}$ Search terms: "immunity" and "liable."

${ }^{21}$ The e-Lib database is an internal IMF database containing more than 3,500 externally published IMF documents relating to surveillance work (i.e., Article IV exercises and Financial Sector Assessment Programs), and other external publications.
} 
prosecution." For country 2, the report (2006) notes that the authorities "stripped deputies and other key public officials of immunity from delinquent actions. The corresponding legislative decree ... eliminated the constitutional provision on immunity of public servants." In the case of country 3 , the report (2005) notes that the new central bank law was well drafted, but that the "only significant variation concerns the lack of immunity. While the Governor has explicit immunity from suit, best practice is to extend such immunity from civil proceedings to other officials, including the bank supervisory staff." In the case of country 4 , the multiple reports $(2007,2008$, and 2009) stressed that the updated banking law only provided "limited immunity to supervisors during the discharge of their duties." For country 5, the report (2002) indicates that the central bank law contains secrecy provisions for the central bank's staff and former staff, and that they are "liable for the damages they cause to the [central bank] in connection with their duties."

In the case of country $6, \mathrm{Kosovo}^{22}$, indemnification arrangements were explicitly addressed as a concern. The 2013 report on Kosovo highlights how the liability and indemnification arrangements were legally sound, but in practice turned out to be disadvantageous to central bank staff:

Legal protection for banking supervisors and other CBK [Central Bank of Kosovo] employees was found to be inadequate. The legal framework explicitly mentions that a member of the Central Bank's decision-making bodies or its staff shall not be liable for acts or omissions performed in the course of the duties and responsibilities, unless it has been proven that such acts or omissions constitute intentional wrongful conduct or gross neglect. It additionally indicates the obligation of the CBK to indemnify them for the legal costs they have incurred in these cases. However, actual cases demonstrate that in practice employees had to cover all the costs resulting from their legal defense until being definitively cleared of any wrongdoing. Only then were staff entitled to claim the reimbursement of these legal costs from the CBK. Discussions with CBK staff indicated that these defense costs may be substantial and the process of getting definitive acquittal can take a long time. Furthermore, even if the employee is cleared of criminal acts, CBK may challenge the expenses submitted and not reimburse any costs until the claimant gets the official declaration from a Court of Justice compelling the CBK to pay for the expenses borne. The lack of proper coverage appears to be a cross-cutting issue, as it applies to bank and other financial sector supervisors, and to deposit insurance fund employees.

\footnotetext{
${ }^{22}$ The report was published externally (see IMF Staff Country Report, 2013, Republic of Kosovo: Financial System Stability Assessment, No. 13/99).
} 
Summarizing, IMF staff have on several occasions raised legal protection issues facing central banks and financial supervisors. The IMF has done so in the context of IMF surveillance, as well as in MCM TA work. However, as noted in Section III, clearer guidance for central bank legal protection, as part of central bank independence and accountability, is lacking.

\section{Protection in What Area}

Most central bank laws do not specify whether criminal, administrative, or civil liability can be assumed. Out of 76 central bank laws, 67 do not contain any specific references to criminal, administrative, or civil liability. However, in most cases these laws do contain references to sanctions and/or fines (Subsection $\mathrm{G}$ ), which indicates that the respective central bank laws refer to administrative liability. ${ }^{23} \mathrm{~A}$ small number of laws refer explicitly to criminal liability (nine), and/or to civil liability (seven). Examples are, for instance, the Philippines, where reference is made to criminal, civil, and administrative liability; similarly, Ecuador ("administrative, civil and criminal law liability"), the Dominican Republic ("notwithstanding criminal and civil liability"), and Lithuania ("guilty of criminal act or violation of administrative law"). Guatemala contains an explicit reference to criminal liability, as does Kazakhstan ("unless criminally punishable action"). In the case of Turkmenistan, the generic but explicit reference to Turkmenistan's laws ("liability based on laws of Turkmenistan") can be assumed to include criminal and civil liability. Pakistan has references to civil liability ("for provisions of the Code of Civil Procedure"), as does Uruguay ("civilly liable"). The central bank law of the Kyrgyz Republic is the only law explicitly referring to tax exemption - which is not uncommon in central bank laws (as noted earlier), and excluded from the scope of this paper. However, what makes this relevant to the purposes of this study is that the law specifically also exempts "regional management" of the Bank of Kyrgyzstan from liability regarding taxes. Figure 9 provides a summary.

Figure 9. Areas of Liability

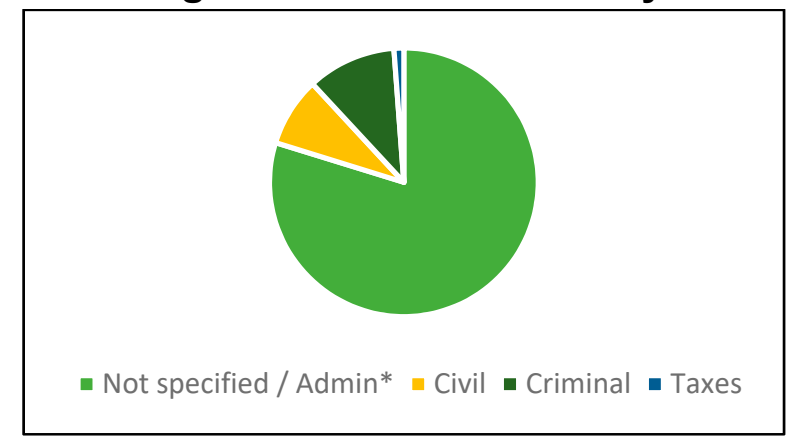

Source: IMF CBLD.

\footnotetext{
${ }^{23}$ This is occasionally combined with explicit references to disciplinary sanctions, for instance, in the case of Kenya.
} 


\section{Who is Protected Subjects}

Immunity is often allocated to "staff" and "Board members." Figure 10 shows that the members of decision-making bodies, such as "the Board," or "the Council," as well as central bank staff in general, are the most often cited for immunity protection. A number of central bank laws refer specifically to special functions, or to more general functions and entities, such as: the comptroller-general (Afghanistan); the auditor (Canada and Luxembourg); "regional management" (Kyrgyz Republic); "structural units" (Turkmenistan); "any person lawfully acting on behalf of the Bank/officer/employee" (Malaysia); "authorities of the central bank" (Guatemala); "workers" (Egypt); and "workers and technical workers of the National Bank ... and its departments" (Kazakhstan). In the case of Cambodia, the central bank law specifies in Article 71 that "any person who violates Article $15.1 \ldots$ shall be liable." However, Article 15 (sub 1) refers to "no officer, employee, or member of the Board of the Central Bank," which defines limits much narrower than "any person," as stated in Article 71.

Figure 10. Subjects of Central Bank Immunity ${ }^{24}$

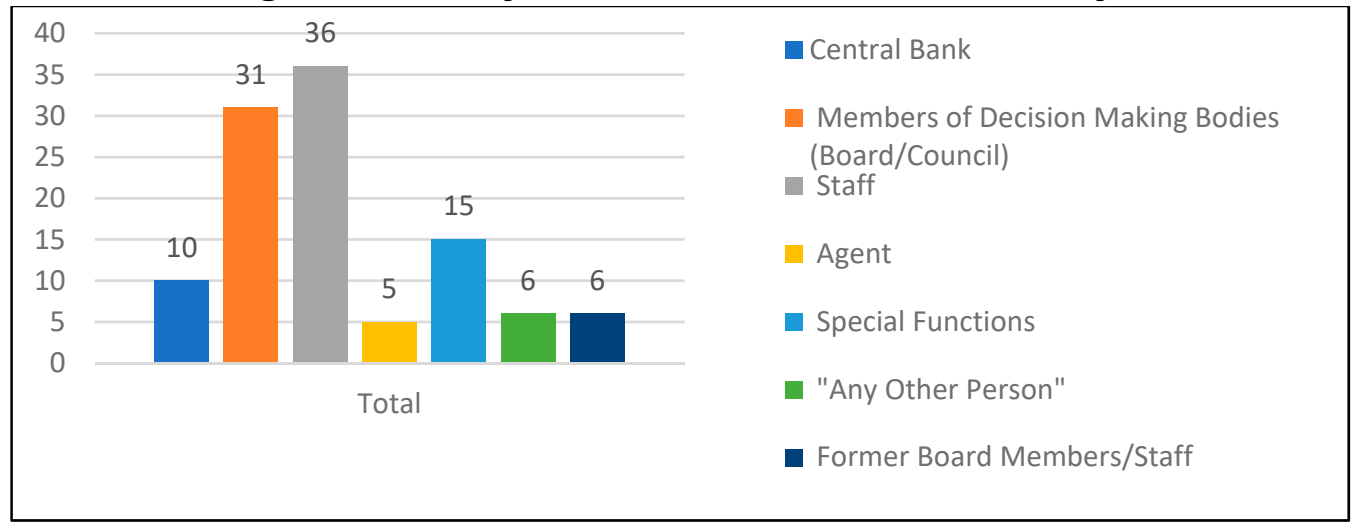

Source: IMF CBLD.

In the case of Libya, immunity only extends to "employees." Article 117 of the central bank law stipulates that "no criminal action may be filed, or any investigative measure taken ... in the crimes attributed to the employees of the Central Bank of Libya, with respect to the performance of their functions." The only exception is if the Governor of the central bank gives his/her explicit permission for filing a criminal action, or taking investigative measures. Though this immunity for staff is not unusual, as listed above, it is interesting to note that the members of the Board of Directors - including the Governor-are not specifically mentioned. This would likely mean that, under the central bank law, the top decision-makers of the central bank are not immune to legal action, nor will they be indemnified by the central bank if such legal action is taken against them. Alternatively, the Board of Directors could be seen as central bank staff, but this would be at odds with CBL practice, where Board

${ }^{24}$ Note that central bank laws can refer to multiple categories of subjects. 
members are separately appointed, remunerated, and dismissed, and their tenure is not guided by general or central bank-specific civil servant statutes.

In the case of China, direct personal liability is assumed for lower levels of central bank staff. The central bank law specifically refers to "managers and other persons directly responsible" (Article 48), and "any employee of the People's Bank of China" (Articles 50 and 51), and arranges for liability for criminal prosecution "if the case constitutes a crime," or for "administrative sanctions if the case is not so serious as to constitute a crime."

The Bahamas excludes liability of directors, but the Bank assumes liability on their behalf. Article 12 (sub 9 and 10) of the central bank law specifies that "no action, suit, prosecution or other proceedings" can be instituted against a director of the central bank, thus making them exempt from liability. Article 12 proceeds to clarify that if a director is exempt in this manner, the "Bank shall be liable to the extent that it would be if that member were an employee or agent of the Bank."

A final interesting case is that of Korea, where the Monetary Policy Committee (MPC) members are liable for monetary policy effects. Article 25 of the central bank law stipulates that "where the Bank of Korea suffers damage caused by the Monetary Policy Committee [MPC] whether willfully or through negligence, all Members present at the meeting involved shall be individually and jointly liable to the Bank of Korea for such damage." Article 25 also exempts from liability those MPC members who "clearly expressed their dissent at the meeting." A similar arrangement exists for Uruguay, where "Directors shall be released from liability... if they were present and noted their dissent" (Article 19).

\section{E. Protected Against What: Standards}

A governing standard for central bank protection is most often not specified in the law, with notable exceptions for good/bad faith, and negligence. A large number of central bank laws (33 out of 76) do not state a specific standard that serves as the benchmark for providing central bank legal liability protection. Those laws that do provide more detail most often list good/bad faith (20), such as those of Bahrain, India, Malta, Mauritius, New Zealand, San Marino, and Seychelles. Other central bank laws refer explicitly to gross negligence, such as those of Belgium, Croatia, Honduras, Korea, Montenegro, Serbia, and Tonga. Some laws combine different standards, such as those of the Philippines ("violation, negligence, abuse, malfeasance, misfeasance, failure to exercise extraordinary diligence"), Oman ("fraudulent or willful act or failure to act"), and Pakistan ("gross negligence or willful misconduct"). Fiji and Namibia list both good/bad faith and negligence.

Some very specific examples of what constitutes good/bad faith and negligence are listed in several central bank laws. Examples include the reference to having been specifically 
convicted by a court of law for a crime (Afghanistan, Iraq, Honduras, Guatemala, Philippines, and Turkey), a generic court ruling (the Dominican Republic, and Trinidad and Tobago), or situations where the central bank can assume explicit liability (Belarus). Figure 11 provides an overview.

Figure 11. Central Bank Liability Standards

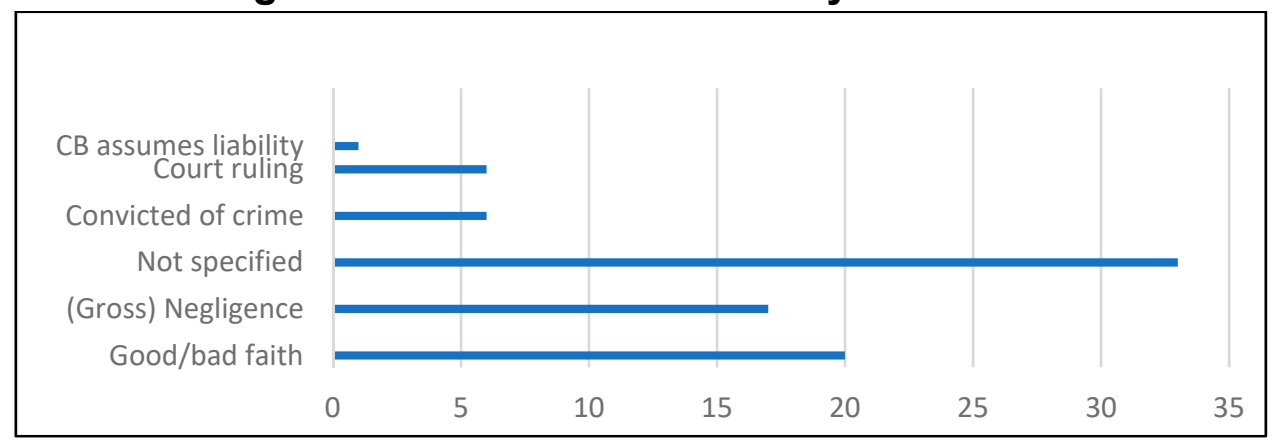

Source: IMF CBLD.

\section{F. Protected in What Manner: Indemnification}

Indemnification arrangements are not particularly common in central bank laws. The majority of central bank laws (58) have either unspecified arrangements for providing indemnification, or none at all. The minority (18) have laws providing explicit arrangements (Figure 12).

Figure 12. Central Bank Law Indemnification Arrangements

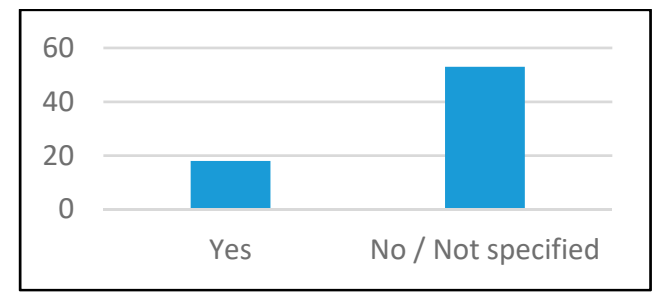

Source: IMF CBLD.

There are several countries that have interesting indemnification arrangements.

- In Bolivia, an emergency situation can lead to exclusion of liability for Board members. Article 60 of the central bank law highlights that in case of a "justified emergency situation," the president of the central bank may, under further specific conditions, make decisions that are normally the prerogative of the Board. In this case, Board members cannot be held liable for those decisions. 
- In the Dominican Republic ${ }^{25}$, the central bank law states that the Monetary and Financial Administration ${ }^{26}$ bears the cost of defending the staff member charged, even if he/she has left the service of the Administration. This also holds for staff dismissed or sanctioned for their refusal to take actions that go against the prohibition to financing public and private entities, but only if those officers challenged these actions before the competent authorities. This seems to be a measure to strengthen the Dominican Republic's stand against fiscal and corporate financing, and as such is a possible measure to strengthen the central bank's independence.

- Guatemala ${ }^{27}$ provides indemnification as well, but its law, unlike those of all other countries that have specific indemnification arrangements, does not include explicit liability arrangements. Rather, liability of Board members and staff seems to be assumed, with the indemnification arrangements providing a backstop.

- $\quad$ Iraq $^{28}$ has more standard language on indemnification of Board members, employees, or agents of the central bank, but also explicitly states that indemnification shall not apply if the person has been convicted of a crime arising out of the underlying activities.

- In the case of New Zealand ${ }^{29}$, it is not the central bank, but rather the government that provides indemnification. The Minister has to present to the House of Representatives a report with details of the circumstances giving rise to the liability, the amount of payment, the person to whom the payment was made, and other relevant matters.

- Papua New Guinea's ${ }^{30}$ indemnification arrangements, somewhat like New Zealand's, include reporting by the Governor to the Minister in the form of a report with details on the circumstances, the amount of payment, the person to whom the

\footnotetext{
${ }^{25}$ Article 7, Monetary and Financial System Law, No. 183-02, November 2002.

${ }^{26}$ The Monetary and Financial Administration is a body consisting of the Monetary Board, the Central Bank, and the Superintendency of Banks, and hence the liability/immunity and indemnification arrangements are extended to staff members of these three organizations.

${ }^{27}$ Article 67, Organic Law of the Banco de Guatemala, 2002, 16-2002 (last amended September 2012).

${ }^{28}$ Article 23, Central Bank of Iraq Law, March 6, 2004.

${ }^{29}$ Article 179A, Reserve Bank of New Zealand Act, 1989 (last amended December 2014).

${ }^{30}$ Article 102 sub 4, Central Banking Act 200 (no. 1).
} 
payment was made, and other relevant matters. This provides transparency and accountability for resources used by the central bank to provide indemnification.

- The central bank law of the Philippines provides specific instances when the "Members of the Monetary Board, officials, examiners, and employees of the Bangko Sentral" may be held liable (Section 16). However, the indemnification arrangements in Section 15 (e) specify that the "Monetary Board shall: "[I]ndemnify its members, other officials of the Bangko Sentral, including personnel of the departments performing supervision and examination functions against all costs and expenses reasonably incurred by such persons in connection with any civil or criminal action, suit or proceedings to which he may be, or is, made a party by reason of the performance of his functions or duties, unless he is finally adjudged in such action or proceeding to be liable for negligence or misconduct.

The costs and expenses incurred in defending the aforementioned action, suit or proceeding may be paid by the Bangko Sentral in advance of the final disposition of such action, suit or proceeding upon receipt of an undertaking by or on behalf of the member, officer, or employee to repay the amount advanced should it ultimately be determined by the Monetary Board that he is not entitled to be indemnified as provided in this subsection.

In the event of a settlement or compromise, indemnification shall be provided only in connection with such matters covered by the settlement as to which the Bangko Sentral is advised by external counsel that the person to be indemnified did not commit any negligence or misconduct."

Though Sections 15 and 16 are not necessarily in conflict with each other, it is interesting to see that the liability article includes the generic "employees," while the indemnification article speaks specifically of personnel of the "supervision and examination functions." This raises the question as to whether the indemnification arrangements are not applicable to other employees of the Bangko Sentral. ${ }^{31}$

\section{G. Limitations to Protection: Fines and Sanctions}

Liability arrangements are often combined with enforcement mechanisms. Central bank laws provide for enforcement mechanisms in the form of fines and other sanctions for members of central bank decision-making bodies, staff, and/or other officials. These mechanisms should provide incentives to act in accordance with the central bank law's provisions. As noted in

\footnotetext{
${ }^{31}$ The Bangko Sentral clarified, upon review of the paper, that: "By its terms, Section 15 grants the Monetary Board sufficient authority to grant indemnity to any Bangko Sentral official in relation to cases arising from the performance of their official functions" (underlining added, AK).
} 
Subsection C, the majority of central bank laws do not specify whether liability is criminal, administrative, or civil in nature.

A significant number of central bank laws explicitly provide for fines or other sanctions. Around 19 percent (27 out of 143 entries $^{32}$ in the CBLD) of central bank laws have arrangements for applying specific fines or other sanctions for violation of provisions in the central bank law (Figure 13). Such sanctions include disciplinary actions, including suspension and termination of contract, financial fines, and imprisonment. The Maldives ${ }^{33}$ specifies the possible sanctions for violating its conflict-of-interest rules as "imprisonment or banishment or house arrest." The other 81 percent of central bank laws that do not contain specific, quantifiable sanctions could, however, contain references to other laws containing specific sanctions. For instance, in Luxembourg ${ }^{34}$ the central bank law contains a reference to penalties listed in the Luxembourg Criminal Code.

Figure 13. Central Bank Laws with Sanctions ${ }^{35}$

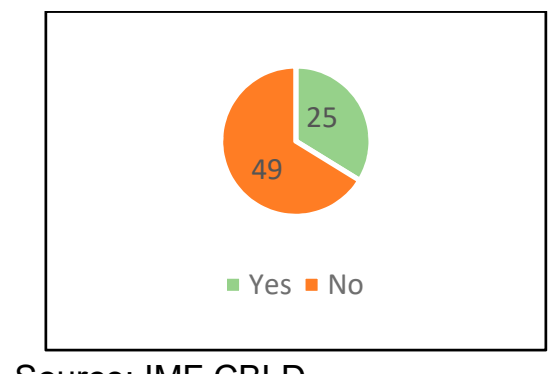

Source: IMF CBLD.

Most actions or omissions that are subject to fines and other sanctions are related to confidentiality issues. Breaches of confidentiality and secrecy (or occasionally dubbed "fidelity," as in Liberia) are most often cited in the laws. Other actions relate to conflicts of interest, general contravention of the central bank law, issues relating to corruption and fraud (for example, in the laws of Kazakhstan, and Trinidad and Tobago), and to certain specific issues. Two examples of the latter are the withholding of information from an external auditor, in the case of Zimbabwe, and "causing injury" in the case of Thailand. Thailand also

\footnotetext{
${ }^{32}$ The percentage is listed of total countries in the CBLD (143), as opposed to of only those having explicit references to liability arrangements (76), given that there are a number of countries that do not contain such explicit references, but still have arrangements for fines and/or sanctions.

${ }^{33}$ Article 10, Maldives Monetary Authority Act, 1981.

${ }^{34}$ Article 33, Organic Law of the Banque Centrale du Luxembourg (last amended April 2015), referring to Article 468 of the Luxembourg Criminal Code.

${ }^{35}$ The following 27 countries have central bank laws that contain one or more quantified sanctions: Bahamas, Bahrain, Belize, Botswana, Cambodia, Canada, Egypt, Fiji, Gambia, Ghana, Guyana, Kazakhstan, Kenya, Liberia, Malawi, Malaysia, Maldives, Mauritius, Namibia, Seychelles, Thailand, Tonga, Trinidad and Tobago, Uganda, UK, Zambia, and Zimbabwe.
} 
has the most extensive list of punishable issues, with nine separately listed penalty provisions.

Fines for violating central bank law provisions range from 7 USD to 700,000 USD. Malawi has the lowest fine, with a maximum of 5,000 K (approximately $6.89 \mathrm{USD}$ ) for violation of its secrecy provision. Malaysia has the highest fine, with a maximum of 3 million Ringgit (approximately 708,466 USD) for violation of its secrecy provision. Other outliers are: Canada (78,330 USD), for anything contravening the Central Bank Act, for holding office as Governor, Deputy Governor, or Director without being eligible, and for verifying false statements; the Bahamas (50,000 USD), for violation of the confidentiality provision; and Thailand (60,313 USD), for violation of several penalty provisions, such as those relating to personal enrichment, and damaging the central bank ${ }^{36}$. On average, central bank laws allocate fines around a maximum of 27,963 $\mathrm{USD}^{37}$ (Figure 14).

Figure 14. Maximum Average Fines in Central Bank Laws

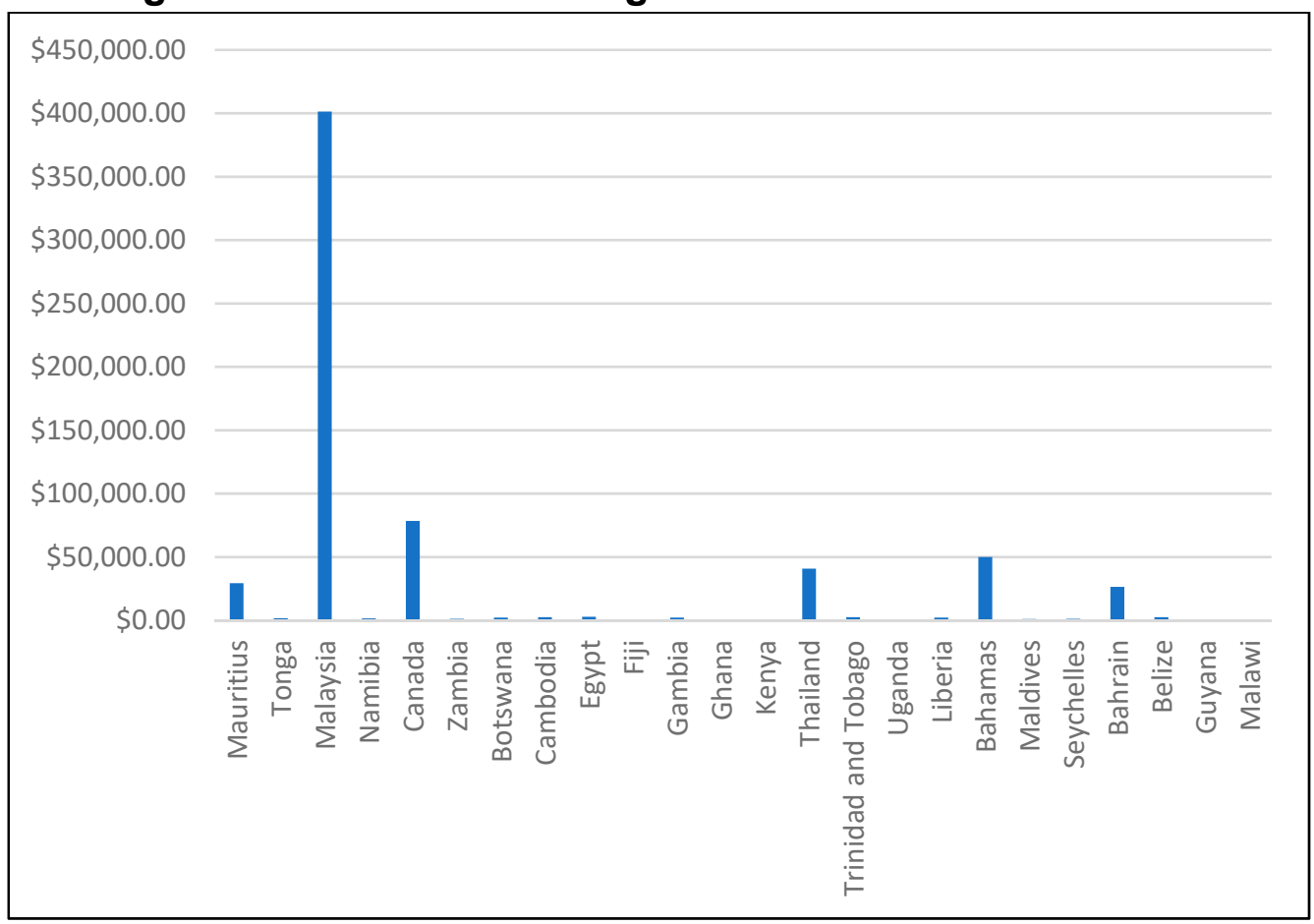

Source: IMF CBLD.

\footnotetext{
${ }^{36}$ The Thai central bank law has an extensive list of "penalties"; more information is shared in Section V: Selected Country Examples.

${ }^{37}$ Based on USD exchange rate of November 3, 2017, as well as, for those cases where the central bank law refers to penalty/fine units instead of fiat currency, the Fees and Fines Act, 1994, last amended 1996, (Zambia), and the Fines (Penalty Units) Act, 2000 (Ghana).
} 
Imprisonment possibilities range from three months to 20 years. In combination with fines, imprisonment possibilities are commonly listed in central bank laws. Zimbabwe has the lowest imprisonment term of a maximum of three months for violating the provision on withholding information from the external auditor, though it also lists a maximum two years' sentence for violation of the secrecy provisions. Canada and Guyana have the lowest average maximum imprisonment terms of six months. In the case of Canada, this is for holding office as a Board member when ineligible, as well as anything that contravenes the Central Bank Act. In the case of Guyana, this is for violating confidentiality provisions. Thailand, in addition to having one of the highest fine structures, has imprisonment terms ranging up to 20 years, or even a life sentence, for the same events as mentioned earlier. The average maximum term for imprisonment of all 24 countries is three years (Figure 15).

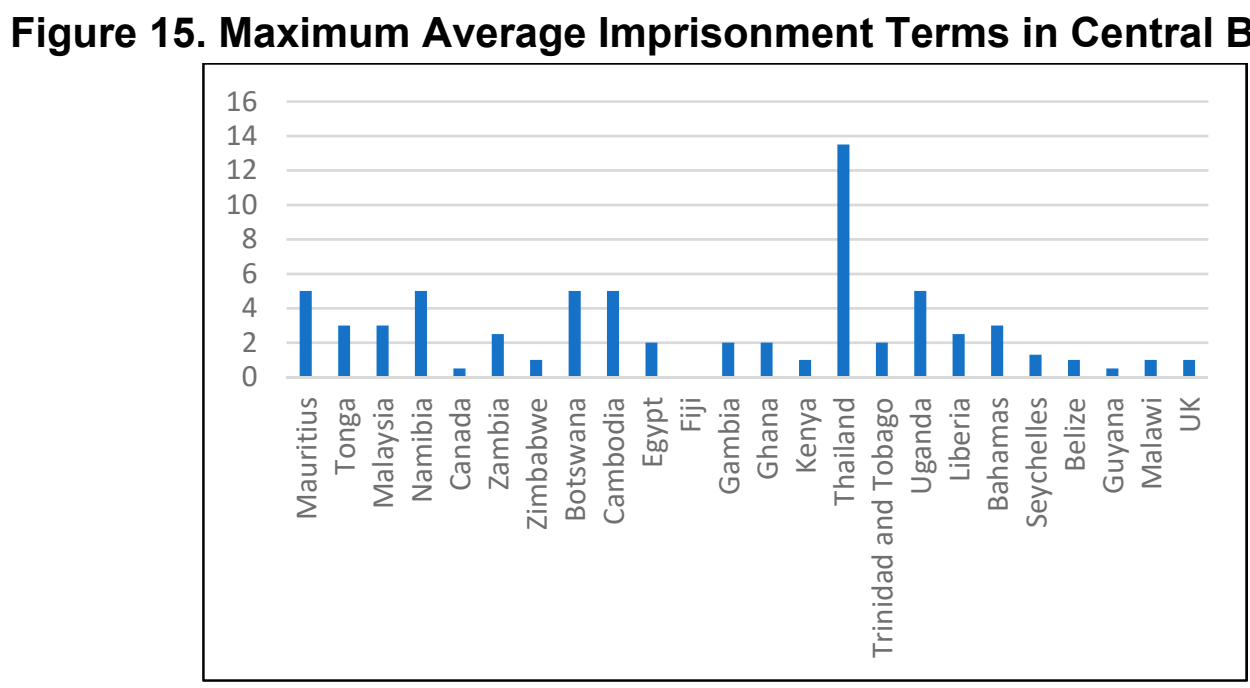

Source: IMF CBLD.

Sanctions in the majority of countries combine financial fines with the possibility of imprisonment. The "and/or" option occurs most often (18 countries) where a fine and/or imprisonment are possible. A small number of countries combine fine and imprisonment, not leaving the option to have one or the other (five countries). Seychelles and Guyana only state "or," indicating that the judicial system will need to make a choice between either the fine or imprisonment. Fiji is an interesting outlier, as its central bank law prescribes a fine (for violation of the secrecy provisions) and does not include the option of imprisonment. Similarly, Bahrain's central bank law includes a fine provision for violating confidentiality, as well as a general reference to imprisonment, but without specifying a term of incarceration.

In summary, given the wide variety of legal regimes and domestic legislation, the fines and sanctions arrangements present in a limited number of central bank laws provide an interesting overview of different country practices. 


\section{Selected COUNTRY EXAMPLES ${ }^{38}$}

This section examines several selected country examples, and provides a concise overview of those central banks' experiences with measures of legal protection. The countries have been chosen to reflect geographical diversity. The country examples are not to be seen as providing a comprehensive overview of country-specific legal arrangements or developments, and are meant for illustrative purposes only.

In practice, court cases against central banks and supervisors have covered a multitude of topics. Annex I provides an illustrative, though far from comprehensive overview of selected news clippings regarding central banks, and the occasional central bank governor, that were sued, either by individuals, supervised entities, or corporate entities. Topics range from issues emerging from central banks' core functions (monetary policy, financial supervision, regulation, resolution, and currency management) to more operational issues (procurement, fraud, and labor issues).

\section{A. Colombia}

As regards legal liability, the Banco de la República is governed by a general legal framework. The Central Bank of Colombia (BdlR) has price stability as its sole responsibility. Legal liability issues are governed by the following general liability provisions and regulations for the State and public entities:

\section{Constitution}

- Article 90. The State will respond materially for the unlawful damages for which it is responsible, caused by actions or omissions on the part of public authorities.

Public servants, disciplinary actions

- Act 678 of 2001 (relating to liability of servants and former public servants) regulates the determination of material responsibility of State agents through the exercise of an action for indemnity or appeal under warranty with the purpose of indemnity.

- Act 1437 of 2011 enacts the Code of Administrative Procedure and administrative litigation.

- Act 734 of 2002 enacts the Single Disciplinary Code.

- Act 610 of 2000 establishes the procedure for the processes of fiscal responsibility which fall within the jurisdiction of comptrollers. ${ }^{39}$

Anti-corruption

\footnotetext{
${ }^{38}$ This section is composed of information shared by the respective central banks.

${ }^{39}$ See further: Act 42 of 1993, Act 617 of 2000, Act 734 of 2002.
} 
- Act 1474 of 2011 lays down rules aimed at strengthening mechanisms for the prevention, investigation, and punishment of acts of corruption, and the effectiveness of public management control.

- Act 1778 of 2016 lays down rules governing the liability of legal persons for acts of transnational corruption, as well as other anti-corruption measures.

The BdIR, however, does not have its own legal regime for liability or immunity. The Central Bank Act (Act 31 of 1992) does not contain any references to liability or immunity. The only peripheral exception to this omission is that Article 14 of the Central Bank Act provides that international reserves cannot be seized.

The BdIR has been sued on different occasions regarding regulatory and administrative measures taken by the Bank and its Board of Directors. Examples include measures related to the methodology for the calculation of the Unidad de Poder Adquisitivo Constante (UPAC), records of foreign investment, and sanctions due to monetary and exchange rate intervention operations. Additionally, there have been suits regarding disputes over labor issues and contracts.

\section{B. Cyprus}

The Central Bank of Cyprus is governed by several statutory provisions limiting its liability as financial supervisor. The Central Bank of Cyprus (CBC) is responsible for price stability, financial stability, and financial integrity, and is an integral part of the European System of Central Banks. It acts within the fields of competence of the system, in accordance with the guidelines and instructions of the ECB. Relevant provisions limiting the CBC's liability relate to supervisory tasks, including the authorization and supervision of credit institutions and payment services providers, and to acts or omissions committed in bad faith or because of gross negligence. These statutory provisions apply on a piecemeal basis, linked to CBC supervisory tasks.

The CBC's liability for supervisory tasks is also exempted through domestic legislation. The Cypriot Business of Credit Institutions Law provides (Section 32), that the CBC, and any person who is a director or an officer of the $\mathrm{CBC}$, shall not be liable for any action, suit, or other legal proceeding for damages for anything done or omitted in the discharge of the functions and responsibilities of the $\mathrm{CBC}$, under this law or under any of the regulations issued under this law, unless it is shown that the act or omission was not in good faith or was the result of gross negligence. There are no specific Cypriot provisions limiting the CBC's liability for the performance of its central banking or other tasks, or limiting the CBC's liability generally as an institution. 
For people involved with the CBC's bank resolution function, liability is limited as well. Section 111 of the Cypriot law, ${ }^{40}$ transposing the European Bank Recovery and Resolution Directive (BRRD), limits the liability of the Minister of Finance, the CBC's Governor, the members of the CBC's Board of Directors, and the CBC's staff to acts or omissions committed in bad faith or because of gross negligence. This does not apply to the $\mathrm{CBC}$ as resolution authority in totality. However, it should be noted that the same law contains principles, including the so-called "not worse off" principle, that define the boundaries of the resolution authority's liability for compensation. Section 86 is relevant in that if the court determining a compensation claim is justified, parties shall accept the complex economic assessments of the facts carried out by the resolution authority as a basis for its own assessment (transposing Article 85.3 of the BRRD).

Administrative recourse could possibly infringe on the CBC's exemption of liability. Article 146 of the Cyprus Constitution provides for administrative recourse to any member of the public adversely affected by an administrative decision. The judgment of the administrative court can only result in an annulment or ratification of the administrative decision. Subsequently, if successful, the complainant may file a second, civil, action for damages. In other words, if a complainant has filed for administrative recourse and is successful, and if the complainant has suffered damage because of the deleterious administrative decision, then the complainant may claim "fair and just" indemnification. ${ }^{41}$ The criterion at this stage seems to be the "but for" causation test between the administrative decision and the damages suffered. There is no limitation of liability in the Constitution in relation to such a claim, and "fair and just" is not adequately represented in case law. As such, it is not completely clear whether the statutory limitation of liability set out in the laws governing the supervision of credit institutions and payment services providers may be activated to limit the liability of the $\mathrm{CBC}$ as a result of a civil action for damages, under article 146(6) of the Constitution.

The CBC is currently a party in many court cases. The CBC is a defendant in hundreds of claims filed in the Cyprus courts by depositors and shareholders of the two major Cypriot banks that went through a resolution process in March 2013. There has been no decision so far in any of these cases. Apart from the administrative recourse described above, a public body may be sued in tort, for example, for negligent supervision or breach of statutory duty. In such a case the limitation of liability in the law may prove applicable, though again there is no case law resolving the matter. It is expected that the CBC's liability in tort, and for breach of statutory duty, will be clarified in the filings against the CBC for possible actions or omissions during the Cyprus banking crisis. These actions are not claims for "fair and just" indemnification, as they do not constitute follow-up to a successful administrative recourse. It is possible that in these actions the CBC's liability will be deemed limited by the

\footnotetext{
${ }^{40}$ Law 22(I)/2016.

${ }^{41}$ The "fair and just" test is enshrined in Article 146(6) of the Constitution.
} 
relevant provision that limits its liability regarding bank supervision, unless there is bad faith or gross negligence.

\section{India}

The Reserve Bank of India (RBI) is responsible for price stability, and, implicitly, for financial stability and financial integrity. Though there is no explicit legal provision for a financial stability objective, the RBI is both the monetary authority and the banking sector regulator, and regarding the functions entrusted to it, it is possible to treat the RBI as having the principal responsibility for both financial stability and price stability. Additionally, there is no explicit legal reference to RBI responsibility for financial integrity, and the RBI is to be consulted by the Indian Government regarding the implementation of the Prevention of Money Laundering Act, 2002 The RBI also monitors compliance of Anti-Money Laundering/Combatting the Financing of Terrorism (AML/CFT) Guidelines. Lastly, the RBI has an implicit responsibility for economic development and financial inclusion, even though the terms "economic development" and "financial inclusion" are not used by the Reserve Bank of India Act, 1934. However, the preamble explains the primary objective of the monetary policy as "to maintain price stability while keeping in mind the objective of growth." Section 54 of the Reserve Bank of India Act, 1934, provides a role for the Reserve Bank in promoting rural credit and development.

India does not have specific legislation on liability exposure of State or State entities. Except for sovereign functions, and those which are specifically provided in the respective statutes (see following paragraph), State and public entities are as liable as any other person or private entity.

The RBI Act does provide specific protection for actions taken in good faith by the Bank or any of its officers. Section 43A of the Reserve Bank of India Act, 1934, provides protection for actions taken in good faith by the "Bank or any of its officers" (from a suit or legal proceedings) in pursuance of exercise of powers under section 42 (maintenance of cash reserves), Section 43 (publication of statements of aggregate liabilities and assets of scheduled commercial banks), and in pursuance of Chapter IIIA (collection and furnishing of credit information). Further, Section 58A of the Reserve Bank of India Act, 1934, provides protection from "prosecution" to the Central Government or the Reserve Bank "or any other person" for anything done or intended to be done in good faith and covered by the Act.

Protection on similar lines is found in other statutes which are administered by the RBI. Examples include the Banking Regulation Act, 1949 (Sections 50, 54), Payment and Settlement Systems Act, 2007 (Section 36), Foreign Exchange Management Act, 1999 (Section 44), and Credit Information Companies (Regulation) Act, 2005 (Section 30). 
The RBI has been a party to many court cases. As the RBI is not given any general immunity from being sued or prosecuted, there have been a large number of cases where the RBI has been made a party to the litigation. The issues of litigation are varied, and range from policy actions taken by the RBI under statutory powers to grievances of RBI staff.

Specific court cases challenging RBI regulatory actions and policies include the following examples:

- Pramod Malhotra \& Ors [Others] versus UOI \& Ors [2004 (3) SCC 415]. The petition challenged a scheme of amalgamation between two banks framed by the RBI, which partially took away the rights of the deposit holders in the transferor bank. The petitioners wanted full repayment. The issue examined was whether the RBI could be made responsible for defaults of the transferor bank, which had been given a branch license by the RBI. The Indian Supreme Court held that the RBI did not have day-today management or control on the transferor bank, and that the relationship of the RBI with creditors or depositors of that bank was not such that it would be just or reasonable to impose a liability for negligence on the RBI. It was also observed that there was no averment regarding bad faith. In doing so, the court relied on the foreign decisions Yuen Kun-yeu v. A-G Of Hong Kong, reported in (1987) 2 All England Law Reports 705; Davis v. Radcliffe, reported in (1990) 2 All England Law Reports 536. The court observed that petitioners having chosen on their own to deposit amounts with the transferor bank cannot claim recovery against the RBI.

- J M D'souza versus RBI [AIR 1946 Bom 510]. This appeal was filed under Section 45 of the Specific Relief Act, against a judgment dated January 22, 1946, praying for a mandatory order to the RBI to discharge and satisfy the unconditional promise to pay the petitioner the sum contained in the bank note, without imposing any condition on the petitioner. The petitioner had, since the coming into operation of the High Denomination Bank Notes (Demonetization) Ordinance, 1946, presented a bank note of Rs 1000 to the RBI with a demand for payment, which was refused by the Bank. The Bombay High Court dismissed the appeal, and held that the statutory method of discharging the RBI's obligation with respect to bank notes under Section 39 of the Reserve Bank of India Act, 1934, was modified by the 1946 Ordinance and therefore an individual's right to exchange notes from the RBI did not exist in the light of Section 6 of the 1946 Ordinance.

- Bimladevi versus UOI \& Anr [1985 58 Comp Cas 361 (Delhi)]. The petition was filed challenging certain provisions of the High Denomination Banknotes (Demonetization) Act, 1978. The petitioners were also aggrieved by the orders passed under the Demonetization Act, proscribing payment of the exchange value of the demonetized notes held by them. The court held that because of Section 3 of the 1978 Act, the banknotes ceased to be a legal tender, and by Section 4 its transfer was also 
prohibited. Consequently, the liability of the Issue Department of the RBI under Section 34 of the Reserve Bank of India Act, 1934, also ceases. Hence, the RBI was under no obligation to exchange such banknotes after the expiry of the period mentioned in the 1978 Act.

\section{Israel}

The Bank of Israel is governed by different legal liability arrangements. The Bank of Israel (BOI) is responsible for price stability, financial stability, consumer protection, financial integrity, and economic development. The BOI is governed by legal liability arrangements in the Torts Ordinance, the Civil Torts Law, and the BOI Law.

The Torts Ordinance allows limiting the BOI's liability if the wrongful act was performed according to the law. Section 6 to the Torts Ordinance-New Version specifies that in a claim with respect to a wrongful act, except for negligence, a defense may arise if the act was performed according to the law or under a lawful authorization. As the BOI operates under the provisions of the Bank of Israel Law and other laws (including banking laws), any actions performed by the BOI, in accordance with such laws, may have the aforesaid defense. The Torts Ordinance also provides for immunity for State employees and employees of public authorities, including the BOI: per Section 7A, a claim will not be brought against an employee in respect of an action performed in the fulfillment of a government office as a public employee, except for actions performed with the intent to cause damage.

This similarly applies under the Civil Torts Law. The Civil Torts Law (State Liability) 57121952 specifies that the State can be found liable in torts, with certain exceptions. One of the exceptions is with respect to liability for an act that was performed within the limits of a lawful authorization (except for negligence, for which it is liable). This provision may or may not also apply to the BOI.

The central bank law itself has no specific liability arrangements. The BOI Law does not provide specific BOI liability arrangements. Neither does it address immunity or indemnification issues regarding the BOI. Nevertheless, there are indemnification arrangements that were agreed upon in specific agreements entered into by the BOI, and that provide certain indemnifications to the BOI, but these are not set by any law.

The BOI, which includes the Banking Supervision Department, has been taken to court over various matters. The majority of these cases dealt with: (1) matters of administrative law, in which BOI administrative acts were challenged in court, including claims relating to the BOI's public tenders; (2) bank consumers' claims, in which the BOI was a formal respondent; and (3) employment-related matters of BOI staff. 


\section{E. Thailand}

The Bank of Thailand is governed by a general law applicable to State agencies. The Bank of Thailand (BOT) is responsible for price stability, general financial stability and the stability of financial institutions, consumer protection, and financial inclusion. Its legal liability is guided by the Act on Tortious Liability of Officials, B.E. 2539 (1996) (the Tortious Liability Act). Section 5 of the Act states, "A state agency shall be liable to an injured person for the consequences of a tortious act committed by its official in the course of his performance of duty. In this case, the injured person may directly sue the state agency but cannot sue the official." As the BOT is a state agency, it falls under the remit of the Tortious Liability Act. Therefore, the BOT is responsible for the consequences resulting from its officials' tortious act committed on duty (Section 5). Similarly, Section 8 of the Tortious Liability Act provides for indemnification of the BOT, in case the BOT has to pay compensatory damages to the injured person. In such a case, the BOT has the right to claim payment for damages from the official who committed the tortious act if the official committed such act on purpose or with gross negligence. The extent of this right of claim has to take into account the degree of gravity of the act, and fairness, with no legal obligation to pay the full amount of the damages. If the tortious act is due to an error or a fault of the state agency or the general operational system, such portion of liability shall also be deducted.

Specific criminal liability arrangements are applicable to BOT officials. There is no criminal liability for the BOT as an entity. However, criminal liabilities for BOT officials are provided in the following provisions of the Bank of Thailand Act B.E. 2485 (1942) as amended:

Section 66: The Governor, the Boards, the officer or employee, having the duty to purchase, manufacture, manage, or keep any property dishonestly, misappropriates such property for himself or herself or other persons, or dishonestly allows other persons to take such property, shall be liable to imprisonment for a term of five to 20 years or a life imprisonment or a fine of 500,000 Baht to 2 million Baht or both.

Section 67: The Governor, the Boards, the officer or employee, wrongfully exercising his or her functions to coerce or induce any person to deliver or to procure a property or any other benefit for himself or herself or other persons, shall be liable to imprisonment for a term of five to 20 years or life imprisonment or a fine of 500,000 Baht to 2 million Baht or both.

Section 68: The Governor, the Boards, the officer or employee, wrongfully demanding, accepting or agreeing to accept for himself or herself or other persons a property or any other benefit for exercising or not exercising any of his or her functions whether such exercise or non-exercise of functions is wrongful or not, shall be liable to imprisonment for a term of five to 20 years or life imprisonment or a fine of 500,000 Baht to 2 million Baht or both. 
Section 69: The Governor, the Boards, the officer or employee, performing or omitting any act in one's own function in consideration of the property or any other benefit demanded, accepted, or agreed to accept by oneself before being appointed as official in that post, shall be liable to imprisonment for a term of five to 20 years or life imprisonment or a fine of 500,000 Baht to 2 million or both.

Section 70: The Governor, the Boards, the officer or employee, having the duty in the purchase, execution, management, or keep of anything dishonestly exercises any of his or her functions damaging the BOT, shall be liable to imprisonment for a term of five to 20 years or life imprisonment or a fine of 500,000 Baht to 2 million or both.

Section 71: The Governor, the Boards, the officer or employee, having the duty of managing or looking after any activity, takes the interest for the benefit of himself or herself or other persons concerning such activity, except for the act assigned by the BOT or under the BOT's regulations, shall be liable to imprisonment for a term of one to 10 years or a fine of 100,000 Baht or 1 million or both.

Section 72: The Governor, the Boards, the officer or employee, having the duty to defray things, defrays such things in excess of what should be defrayed for the benefit of himself or herself or other person, shall be liable to imprisonment for a term of one to 10 years or a fine of 100,000 Baht or 1 million or both.

Section 73: The Governor, the Boards, the officer or employee, wrongfully exercising or not exercising any of his or her functions to the injury of any person, or dishonestly exercising or omitting to exercise any of his or her functions, shall be liable to imprisonment for a term of one to 10 years or a fine of not exceeding 100,000 to 1 million Baht or both.

The BOT has been sued in the administrative counts for negligence of its official duties. These cases relate predominantly to the BOT's duties of regulating financial institutions, and were filed by several consumers who were dissatisfied with the services of the financial institutions under the BOT's supervision. These cases are still ongoing in the courts. 


\section{Conclusion}

Legal protection is a key element of central bank laws. Most central bank laws provide some arrangements for legal protection for the central bank, and often for the financial supervisor as well - in particular, when the financial supervisor is part of the central bank. The scope and nature of these provisions differ from country to country. However, certain general observations can be made:

- Most central bank laws do not specify whom they provide legal protection against;

- The majority of central bank laws contain explicit references to liability, often excluding or limiting liability, in particular for decision-makers and staff, often without providing explicit details on indemnification arrangements; and

- In numerous cases, IMF surveillance and MCM technical assistance stresses the need for legal protection of central banks and financial supervisors.

In all cases, legal protection is crucial for safeguarding the independence of central banks and financial supervisors. Though the need for independence of the central bank, and to a certain extent of the financial supervisor and resolution authority, is not without debate, it unquestionably forms a cornerstone for safeguarding the freedom of the central bank to make decisions that are removed from undue influence by government, and others. Protection offered to the central bank's decision-makers and its staff ensures to a certain extent that difficult policy decisions can be made without the fear of direct repercussions.

However, accountability is required as a counterweight to legal protection. A central bank and financial supervisor do not operate in a power vacuum, and need to be held accountable for their actions and omissions. Where legal protection broadens the possibility for making independent decisions, ex ante, accountability arrangements should ensure that central bank decision-makers, staff, and others are answerable, ex post, for the way and manner this decision-making power has been used. Central bank laws can contain provisions on transparency, including reporting requirements to the Minister and/or to Parliament.

Therefore, legal protection should be appropriate, and possibly function-specific. To strike a proper balance between legal protection safeguarding a central bank's independence, by means of excluding or limiting liability, and ensuring that a central bank can be held accountable, legal protection needs to be tailored to the country-specific context. This includes the overall legal framework and legal tradition and the functioning of the judicial system, as well as the position of the central bank within the country. Such appropriate protection could also include a function-specific application, depending on the function, as is already the case for supervisory and regulatory entities, based on the relevant international principles.

The IMF has stimulated discussion on legal protection of central banks and financial supervisors. Through its surveillance and technical assistance work, the IMF promotes the 
enhancement of legal protection of central banks and financial supervisors. In those cases where this was less successful, as some of the repeated recommendations in reports show, publication of the recommendations and discussion with the authorities nonetheless contributed to a greater awareness of central bank governance issues. Further analysis of central bank laws, taking specific legal traditions into consideration, as well as the IMF's databases on the types of central bank liability (criminal, administrative, and/or civil), would be helpful.

Legal protection remains important. The selected country cases and the anecdotal press clippings illustrate the fact that, though de jure legal protection arrangements might be included in central bank laws, de facto court cases, initiated by financial institutions, consumers, depositors, and disgruntled current and former central bank employees, for anything varying from presumed incorrect policy actions to labor rights violations, are not excluded from litigation. As central banks and supervisors keep operating in difficult, complex market situations, their actions will remain under continuous scrutiny, and will undoubtedly be challenged. Proper legal protection, as a tool for central bank independence, but with accountability arrangements also in place, will therefore remain crucial. 


\section{REFERENCES}

Arda, A., "Legal Protection of Central Bankers in the Wake of the Financial Crisis."

Presentation made at the Türkiye Cumhuriyet Merkez Bankasi, November 13-14, 2013.

BCBS, 2011, Core Principles for Effective Banking Supervision. Basel: Bank for International Settlements.

BIS, 2009, Issues in the Governance of Central Banks-A Report from the Central Bank Governance Group. Basel: Bank for International Settlements.

BIS, 2011, Central Bank Governance and Financial Stability. Basel: Bank for International Settlements.

Dijkstra, R.J., 2012, "Liability of Financial Supervisory Authorities in the European Union," Journal of European Tort Law, No. 3, pp. 34-377.

FSB, 2014, Key Attributes of Effective Resolution Regimes for Financial Institutions. Basel: Bank for International Settlements.

IMF, 2010, “The Making of Good Supervision: Learning to Say 'No,"” SPN/10/08. Washington: International Monetary Fund.

Khan, A., 2016, Central Bank Governance and the Role of Nonfinancial Risk Management, IMF Working Paper 16/34. Washington: International Monetary Fund.

Khan, A., 2017, Central Bank Legal Frameworks in the Aftermath of the Global Financial Crisis, IMF Working Paper 17/101. Washington: International Monetary Fund.

Lybek, T., and J. Morris, 2004, Central Bank Governance: A Survey of Boards and Management, IMF Working Paper 04/226. Washington: International Monetary Fund.

Nolan, D., 2013, “The Liability of Financial Supervisory Authorities," Journal of European Tort Law, No. 2, pp. 190-222.

OECD, 2015, Guidelines on Corporate Governance of State-Owned Enterprises. Paris: OECD Publishing.

Wachtel, P., 2017, Central Bank Independence: More myth than reality (preliminary draft). Colloquium on "Money, Debt and Sovereignty," Université de Picardie Jules Verne, Amiens, France, December 11-12. 


\section{Annex I - Overview of Selected News Articles on Central Bank Court Cases}

The overview is not meant to be exhaustive, and is intended for illustrative purposes only. All case descriptions are "alleged," and are copied from the respective sources without further verification.

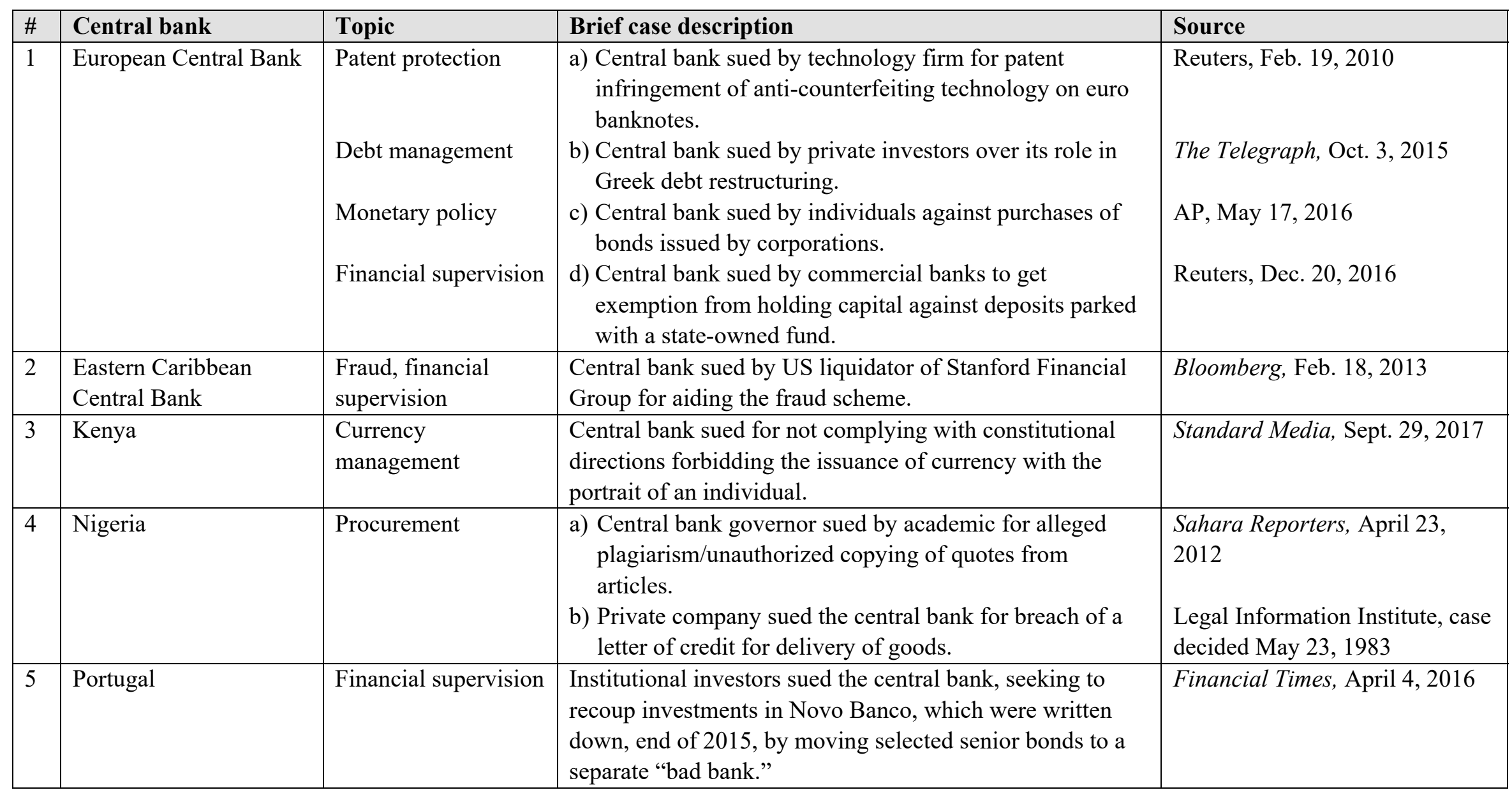




\begin{tabular}{|l|l|l|l|l|}
\hline 6 & Sri Lanka & Fraud & $\begin{array}{l}\text { Central bank threatened to be sued by former President of } \\
\text { the country over bond scam. }\end{array}$ & Indian Express, Feb. 25, 2017 \\
\hline 7 & Thailand & $\begin{array}{l}\text { Monetary/exchange } \\
\text { rate policy }\end{array}$ & $\begin{array}{l}\text { A former central bank governor was taken to court by the } \\
\text { central bank for alleged grave negligence in making } \\
\text { foreign exchange reserves decisions during the country's } \\
\text { 1997 economic crisis. }\end{array}$ & $\begin{array}{l}\text { CNN, May 31, 2005 } \\
\text { Bangkok Post, Oct. 6, 2016 }\end{array}$ \\
\hline 8 & Uganda & Financial supervision & $\begin{array}{l}\text { a) Central bank was sued for failing to properly supervise } \\
\text { Crane Bank. } \\
\text { b) Central bank was sued by owner of Crane Bank for } \\
\text { breach of the settlement arrangement. }\end{array}$ & Monitor, July 18, 2017 \\
\hline 9 & United States & Cyberver, Aug 7, 2017 & $\begin{array}{l}\text { Central Bank of Bangladesh is examining possible law suit } \\
\text { against Federal Reserve Bank of New York for allowing } \\
\text { fraudulent payment instructions to go through. }\end{array}$ & The Hindu, March 23, 2016 \\
\hline 10 & Zimbabwe & Labor issue & $\begin{array}{l}\text { Central bank sued by own staff for failing to pay them for } \\
\text { three months. }\end{array}$ & Sunday Standard, April 5, 2009 \\
\hline
\end{tabular}

